\title{
Regulation of mRNA transport, localization and translation in the nervous system of mammals (Review)
}

\author{
CARLO MARIA DI LIEGRO $^{1 *}$, GABRIELLA SCHIERA ${ }^{1 *}$ and ITALIA DI LIEGRO ${ }^{2}$ \\ ${ }^{1}$ Department of Biological Chemical and Pharmaceutical Sciences and Technologies (STEBICEF), \\ I-90128 Palermo; ${ }^{2}$ Department of Experimental Biomedicine and \\ Clinical Neurosciences (BIONEC), University of Palermo, I-90127 Palermo, Italy
}

Received November 7, 2013; Accepted December 9, 2013

DOI: $10.3892 /$ ijmm.2014.1629

\begin{abstract}
Post-transcriptional control of mRNA trafficking and metabolism plays a critical role in the actualization and fine tuning of the genetic program of cells, both in development and in differentiated tissues. Cis-acting signals, responsible for post-transcriptional regulation, reside in the RNA message itself, usually in untranslated regions, $5^{\prime}$ or $3^{\prime}$ to the coding sequence, and are recognized by trans-acting factors: RNA-binding proteins (RBPs) and/or non-coding RNAs (ncRNAs). ncRNAs bind short mRNA sequences usually present in the 3'-untranslated (3'-UTR) region of their target messages. RBPs recognize specific nucleotide sequences and/or secondary/tertiary structures. Most RBPs assemble on mRNA at the moment of transcription and shepherd it to its destination, somehow determining its final fate. Regulation of mRNA localization and metabolism has a particularly important role in the nervous system where local translation of pre-localized mRNAs has been implicated in developing axon and dendrite pathfinding, and in synapse formation. Moreover, activity-dependent mRNA trafficking and local translation may underlie long-lasting changes in synaptic efficacy, responsible for learning and memory. This review focuses on the role of RBPs in neuronal development and plasticity, as well as possible connections between ncRNAs and RBPs.
\end{abstract}

\section{Contents}

1. Introduction

2. Regulatory signals and regulatory factors

Correspondence to: Dr Italia Di Liegro, Department of Experimental Biomedicine and Clinical Neurosciences (BIONEC), University of Palermo, Via del Vespro 129, I-90127 Palermo, Italy

E-mail: italia.diliegro@unipa.it

${ }^{*}$ Contributed equally

Key words: post-transcriptional regulation, RNA-binding proteins, neurons, nervous system, synaptic plasticity, RNA metabolism, mRNA pre-localization, non-coding RNA
3. Messenger RNA trafficking and localization in neurons

4. Locally regulated stabilization and/or translation of pre-localized mRNAs in neurogenesis

5. RBPs linked to human disease

6. Conclusion and future directions

\section{Introduction}

Post-transcriptional regulation is fundamental for determining the appropriate time and place at which a given mRNA is translated and its half-life. Processes as different as cell fate determination during embryogenesis, differentiated cell response to physiologic or stress cues, and stabilization of memories depend on pre-localization and the regulated translation of specific sets of mRNAs. RNA is thus the carrier of the two messages that are to be translated into the protein and of the detailed information concerning where and whether it is to be translated (1). Moreover, while mRNAs encoding housekeeping proteins, such as cytoskeletal components, have on average short decay rates of days, mRNAs encoding regulatory proteins, such as transcription factors, have half-lives of minutes (2). Deregulation of both short-lived mRNA stability and/or localization/translation may cause marked alterations in cell function, ranging from cancer to cell death.

Post-transcriptional regulation largely depends on the activity of a number of general and specific RNA binding proteins (RBPs) that recognize consensus sequences and/or structural features, mainly located in the 3'-untranslated region (3'-UTR) of mRNAs but that can also be present in the 5'-untranslated- (5'-UTR) and coding sequences. Several RBPs bind primary transcripts (heterogeneous nuclear RNAs: hnRNAs) following transcription (Fig. 1), leading to the assembly of nascent heterogeneous nuclear ribonucleoprotein complexes (hnRNPs). In the context of hnRNPs, hnRNA undergoes 3'-end cleavage and the addition of a poly(A) tail, and these events promote transcription termination and the assembly of a dynamic enzymatic complex, the spliceosome. The spliceosome, which contains five small nuclear RNPs (snRNPs) and numerous proteins, is responsible for intron selection and removal, and the appropriate joining of exons (3). RNA protein interactions in the spliceosome are crucial for 
determining which sequences should be retained in the mature message, and function as checkpoints before mRNA transport to the cytoplasm. Conformational perturbations within the spliceosome can control alternative splicing decisions (4). Notably, the molecular interactions within the spliceosome may be even more complex during maturation of pre-mRNAs containing very large introns, for which nested splicing events have been recently suggested (5), as well as of mRNAs containing ultrashort introns (6). The fact that crucial decisions are taken during maturation of the primary transcript suggests that the nuclear history of mRNA can be determined for its stability and translation into the cytoplasm (7). The nucleo-cytoplasmic traffic of RNPs occurs through the nuclear pore complex (NPC), and requires nuclear export signals (NES), present on RBPs. The directionality of nucleo-cytoplasmic traffic depends on remodelling of the mRNPs on the cytoplasmic side of the nuclear envelope (8). Several RBPs also contain nuclear localization signals (NLS), and shuttle between the nucleus and the cytoplasm. Modulation, by post-translational modifications, of RBP ability to enter the nucleus and/or to exit from it may be one of the earliest regulatory steps in the pathway leading to the translation of a given mRNA.

Once in the cytoplasm, mRNPs are capable of binding to motor proteins, which mediate their transport, in a translationally inactive form, along the cytoskeletal filaments. At their final destinations, mRNAs are immediately translated or stored until a signal-dependent remodelling of mRNPs occurs. Molecular mechanisms allowing the selective translation of pre-localized mRNAs are of the most importance in both the developing and adult nervous system, and can be at the basis of learning and memory processes.

\section{Regulatory signals and regulatory factors}

General. Post-transcriptional regulation depends on the sequences/structures present on mRNA (cis-acting elements), and trans-acting factors, and the ability to recognize them. In addition, RNA protein interactions can be modulated over time by extracellular signal transduction pathways that target RBPs, inducing their post-translational remodelling.

Cis-acting determinants present on $m R N A$. RNA is a highly dynamic molecule able to fold into complex secondary and tertiary structures, based on standard $C: G / A: U$ base pairs as well as on non-Watson-Crick interactions (9-14) generating different conformers with different biological activities. During folding, RNA has the tendency to be trapped in inactive tridimensional structures (15) and it is not easy to envisage thermodynamically predominant isoforms of a given mRNA $(16,17)$. Two main classes of RNA-binding proteins cooperate in vivo with RNA in the acquisition of functional structures: i) RNA chaperones, such as RNA helicases of the DEAD-box family, or unwindases (18-20), which prevent and/or resolve misfolded structures $(15,21-23)$, and ii) tertiary structure-binding proteins, which are able to recognize and stabilize the 'correctly' folded RNAs (induced fit) (16).

In general terms, cis-acting determinants or 'zipcodes' can be formed by simple sequences and/or secondary/tertiary structure elements $(24,25)$. Fig. $2 \mathrm{a}$ is a schematic drawing of mRNA structural organization. Zipcodes may occasionally function independently of the precise sequence context in which they are normally found: they are capable of driving the localization of any reporter message to which they are fused. However, not all the zipcodes are position-independent. Some RNAs contain multimers of a single motif, while others contain multiple cis-acting determinants; in both cases, multiple zipcodes mediate multiple steps in the localization process by acting synergistically (25).

Trans-acting factors: RNA-binding proteins (RBPs) and non-coding RNAs (ncRNAs). Cis-acting determinants are recognized by RBPs that assemble on RNA, forming RNA protein particles (RNPs) of different and regulated composition. In most cases, trans-acting factors recognize a specific secondary structure in the RNA, often a hairpin stem-loop structure, along with a small number of specific anchoring nucleotides (25). RNA recognition and binding is mediated by different families of RNA-binding domains, a summary of which is shown in Fig. 2b.

Most RBPs contain more than one RNA-binding domain, which has been shown to act synergistically by intra-molecular- $(26,27)$ or inter-molecular-cooperativity (28). Conversely, the same RBP is able to recognize different sequence elements within the target mRNA, and recognition can require the correct spatial positioning of these sequences (29). More importantly, binding of all elements can affect overall affinity of the RBP for the target mRNA. This cooperative effect depends on significant unfolding or the structural changes the mRNA undergoes after the first contact with the $\operatorname{RBP}(26,30)$. This observation is important when we consider that mRNA also interacts with non-coding RNAs, the regulatory role of which has been recently recognized (see below).

A widely diffused RNA-binding domain is the ribonucleoprotein (RNP) motif or RNA recognition motif (RRM). RRMs contain $\sim 90$ amino acids and one or more copies of it were initially identified in proteins that bind heterogeneous nuclear (hn) pre-mRNA (hnRNP) (12,31). Proteins present in hnRNPs also contain a variable number of Arg-Gly-Gly (RGG) repeats that in most cases seem to be non-specific binding domains, acting in cooperation with other RNA-binding domains (31). In alternative or in addition to RRM and RGG motifs, hnRNPs may contain one or more domains known as K-homology $(\mathrm{KH})$ after hnRNP K, the first protein in which the motif was identified (32).

Several RBPs contain an RNA-binding domain with a preference for double-stranded stretches of RNA (dsRNAbinding motif: DSRM). The prototypic DSRM was found in Staufen (Stau), a protein required for maternal mRNA localization in Drosophila egg (33). Stau is also involved in the regulation of mRNAs required for memory formation in both Drosophila and Aplysia $(34,35)$. In mammals, two Stau isoforms are present, which bind to distinct, although overlapping, sets of mRNAs (36). Recently, Stau has been reported to regulate pyramidal cell spine morphology via NMDA receptor-mediated synaptic plasticity (37). Moreover, it probably forms a functional complex with the fragile $\mathrm{X}$ mental retardation protein (FMRP) and the $43 \mathrm{kDa}$ transactive response DNA-binding protein (TDP-43), both of which are related to nervous system pathologies (see below) (38).

The most abundant protein family in the mammalian genome is probably constituted by zinc-finger-containing 


\section{RNA transcription}
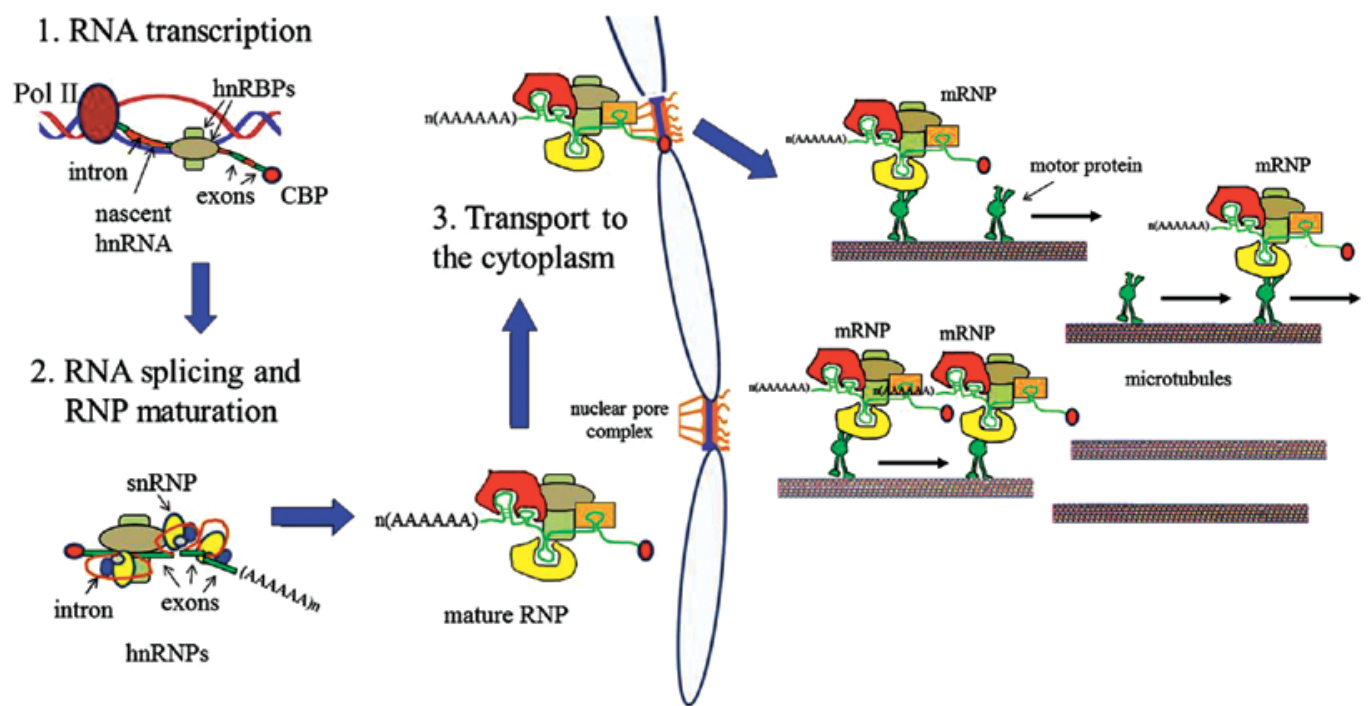

\section{nucleus}

\section{cytoplasm}

Figure 1. Post-transcriptional fate of mRNA. During transcription (step 1) by RNA Polymerase II (Pol II), the nascent heterogeneous nuclear primary transcript (nascent hnRNA) is complexed with RNA-binding proteins (RBPs) (hnRBPs), some of which are also involved in splicing (step 2), together with small nuclear ribonucleoparticles (snRNPs). In the splicing process, introns are removed and exons are joined together, to obtain a mature mRNA, complexed with RBPs [mature RNA-protein particles (RNP)], ready to be transported to the cytoplasm (step 3), through interaction with proteins of the nuclear pore complex. In the cytoplasm, RNPs attach to cytoplasmic motor proteins, which mediate the microtubule-dependent transport of mRNA to its final destination.

proteins (39), which contain several types of Cys-Cys (CC) or Cys-His $(\mathrm{CH})$ motifs, and were considered primarily as transcriptional regulators. The first identified zinc-finger containing protein, TFIIIA, is necessary for the transcription, by RNA polymerase III, of the genes encoding ribosomal $5 \mathrm{~S}$ RNA, but is also able to bind ribosomal 5S RNA itself in the $7 \mathrm{~S}$ ribonucleoparticles stored in the cytoplasm of amphibian oocytes. Similarly, many other members of the family are able to bind the two classes of nucleic acids or RNA only $(40,41)$.

In mammals, one example of $\mathrm{CCHH}$ zinc finger domaincontaining RBP is hZFP100, involved in the processing of histone mRNAs (42), while a $\mathrm{CCCH}$ domain characterizes tristetraprolin (TTP), which participates in mRNA decay (43). TTP and the other members of the TIS11 family have a crucial role in post-transcriptional regulation, targeting for degradation ARE-containing mRNAs $(44,45)$. In rat brain, an interaction between PABP (poly-A binding protein) and Makorin 1 (MKRN 1), a RING zinc finger protein, has been recently demonstrated (46). By binding to PABP and dendritic mRNAs, MKRN1 was able to regulate translation at synapses in response to stimuli inducing synaptic plasticity (46).

Another domain, found in RBPs as well as in DNA-binding proteins, is the cold-shock domain (CSD), first identified in bacterial RNA chaperones and then found in a number of eukaryotic proteins (Y-box proteins), which is able to interact with single-stranded DNA and/or RNA (47). In one of the best studied CSD-containing proteins, the Xenopus protein FRGY2, the CSD was shown to be important for the sequence-specific RNA-binding, while a second tail domain was involved in translation repression (48). Y-box protein (YB)-1, the prototypic member of the CSD-containing protein family, is both a transcription factor and a major component of mRNPs. We recently demonstrated that in nuclear extracts from rat brain, YB-1 interacts with a group of proteins that bind the mRNA encoding the histone variant $\mathrm{H} 1^{\circ}$. Among these proteins another CSD-containing protein, CSD-C2, also known as PIPPin (49), was present (50).

Proteins that do not contain any conventional RNA-binding domains have been shown to bind RNA. The variety of trans-acting domains should therefore be larger than expected. Examples of proteins, already known for other well-established functions, which are also able to bind RNA, include thymidylate synthase (51), mitochondrial glutamate dehydrogenase (52), cytosolic glyceraldehyde-3-p dehydrogenase (53), and the calmodulin-binding protein PEP-19 (also known as PCP-4 in humans) (54).

Besides RNA-binding proteins, regulation of the mRNA metabolism also involves non-coding RNAs (ncRNAs). A high proportion of complex genomes gives rise to ncRNAs, among which the most widely studied class is that of miRNAs, small RNAs of $\sim 22$ nucleotides (nt) that recognize specific sequences present in the 3'-UTR of target mRNAs. By binding their target mRNAs, miRNAs mediate post-transcriptional gene silencing, through an increase of mRNA decay rate and/or inhibition of translation (55-58). Deregulation of miRNA functions is involved in cancer development (59-61) and in a number of other human diseases, including neurological syndromes (62).

Biogenesis of miRNA is a multi-step process that starts in the nucleus with the transcription of a long precursor (pri-miRNA). Following the sequential action of the RNase III enzymes Drosha and DICER, a dsRNA of 22 nt is produced in the cytoplasm, resulting in the formation of the RNA-induced silencing complex (RISC) in which only one strand of the dsRNA is inserted that contains members of the Argonaute (Ago) protein subfamily as catalytic endonuclease components (56).

An increasing number of functional interactions have been identified between RBPs and miRNAs. In general 

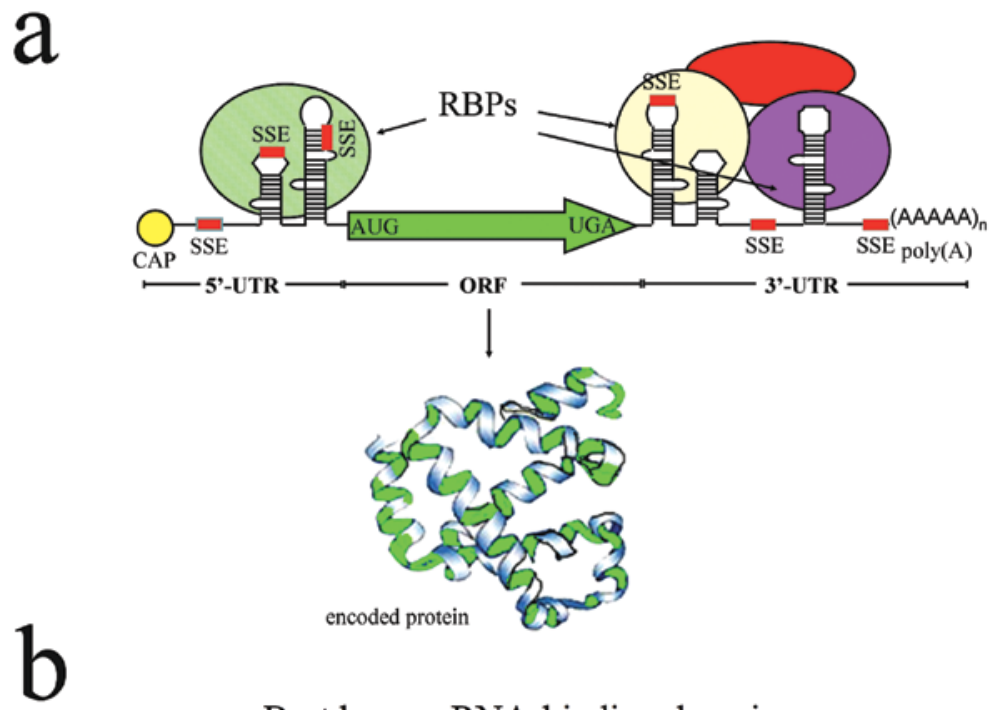

Best known RNA-binding domains

\begin{tabular}{|c|c|c|}
\hline Name & Secondary structure & Examples \\
\hline $\begin{array}{l}\text { Arginine-Rich Motif } \\
\text { (ARM) }\end{array}$ & $\begin{array}{l}\text { Three kinds of structures: } \\
\beta \text {-hairpin, } \alpha \text {-helix, helix bend helix }\end{array}$ & $\begin{array}{l}\text { hnRNP K } \\
\text { hnRNP U }\end{array}$ \\
\hline $\begin{array}{l}\text { Cold shock domain } \\
\text { (CSD) }\end{array}$ & $\begin{array}{l}\text { five-stranded anti-parallel } \beta \text {-barrel with an } \\
\text { oligonucleotide/oligosaccharide-binding fold }\end{array}$ & $\begin{array}{c}\text { YB-1, } \\
\text { CRHSP-24, } \\
\text { CSDC2 (PIPPin) }\end{array}$ \\
\hline $\begin{array}{c}\text { double-stranded RNA binding motif } \\
\text { (dsRBM) }\end{array}$ & $\alpha \beta \beta \beta \alpha$ topology & $\begin{array}{l}\text { Staufen } \\
\text { Drosha }\end{array}$ \\
\hline $\begin{array}{c}\text { hnRNP K homology }(\mathrm{KH}) \\
\text { domain }\end{array}$ & $\begin{array}{l}\text { type I, eukaryotic: } \beta \alpha \alpha \beta \beta \alpha \text { topology } \\
\text { type II, prokaryotic: } \alpha \beta \beta \alpha \alpha \beta \text { topology }\end{array}$ & $\begin{array}{c}\text { hnRNP K } \\
\text { FMRP } \\
\text { Noval }\end{array}$ \\
\hline $\begin{array}{c}\text { RNA Recognition Motif (RRM) } \\
\text { or } \\
\text { RNA binding domain (RBD) } \\
\text { or } \\
\text { Ribonucleoprotein domain (RNP) }\end{array}$ & $\begin{array}{l}\beta_{1} \alpha_{1} \beta_{2} \beta_{3} \alpha_{2} \beta_{4} \text { : forming a four- stranded } \\
\text { beta sheet packed against two alpha helices }\end{array}$ & $\begin{array}{c}\text { Msil } \\
\text { Elav/Hu } \\
\text { PABP } \\
\text { CPEB } \\
\end{array}$ \\
\hline Zinc finger domain $(\mathrm{ZnF})$ & $\begin{array}{l}\beta \beta \alpha \text { protein fold in which a } \beta \text { hairpin and an } \\
\alpha \text { helix are pinned together by a } \mathrm{Zn} \text { ion. } \\
\text { Classified depending on the amino acids that } \\
\text { interact with } \mathrm{Zn} \text { ion in: } \mathrm{CCHH}, \mathrm{CCCH} \text { or } \\
\mathrm{CCCC}\end{array}$ & $\begin{array}{c}\text { Hzfp100 }(\mathrm{CCHH}) \\
\text { TTP }(\mathrm{CCCH}) \\
\text { MKRN1 }(\mathrm{CCCH})\end{array}$ \\
\hline
\end{tabular}

Figure 2. Structural organization of mRNA and best known RNA-binding domains. Schematic representation of (a) mRNA molecule, showing both the open reading frame (ORF, from an AUG codon to a UGA codon) encoding for a protein, and the untranslated regions (UTR) 3'- and 5'- to the coding sequence. The cap structure at the 5'-end, and the poly(A) tail at the 3'-end are also indicated. As described in the text, RNA-binding proteins (RBPs) recognize and bind either secondary/tertiary structures (stem loops in the figure), or simple sequence elements (SSE). The most common RNA-binding domains are summarized in b.

terms, RBPs and miRNAs may cooperate or counteract in the regulation of a given mRNA. Examples of the two types of RBPs-miRNA interplay have been identified in different types of cancer cells (63). The role of miRNAs in neurons has also been identified and previously assessed $(64,65,66)$. Since a number of RBPs are uniquely, or almost uniquely, expressed in the nervous system, the possibility exists that they are capable of regulating the interaction among mRNAs and certain groups of miRNAs in a specific way, in turn regulating the establishment and/or maintenance of the unusual functions of this tissue.

Signaling pathways that control $m R N A$ localization and metabolism. All the steps of RNA metabolism, from splicing and maturation in the nucleus to final degradation, are affected by the cellular microenvironment and by extracellular signals, such as hormones, growth factors, physical and chemical stress stimuli, as well as neurotransmitters (Fig. 3). All these cues are known to affect mRNA stability and translation by triggering signaling pathways that cause post-translational modifications of specific RBPs. A variety of post-translational modifications affecting RBPs have been identified, including serine/threonine phosphorylation, proline hydroxylation, arginine/lysine methylation, lysine ubiquitination or SUMOylation and lipidation. These chemical modifications influence affinity and/or specificity of protein-protein and/or RNA-protein interactions, and are consequently critical for the rapid remodelling of ribonucleoprotein complexes and for the stability and localization of mRNAs $(2,67)$.

Localized mRNAs are transported close to the plasma membrane or organelles, suggesting that membrane-bound kinases play an important role in the regulation of the translation of localized transcripts, in response to extracellular signals (68). Extracellular cues also activate retrograde pathways that may even reach the nucleus, inducing the modification of chromatin organization of genes and, in turn, gene 


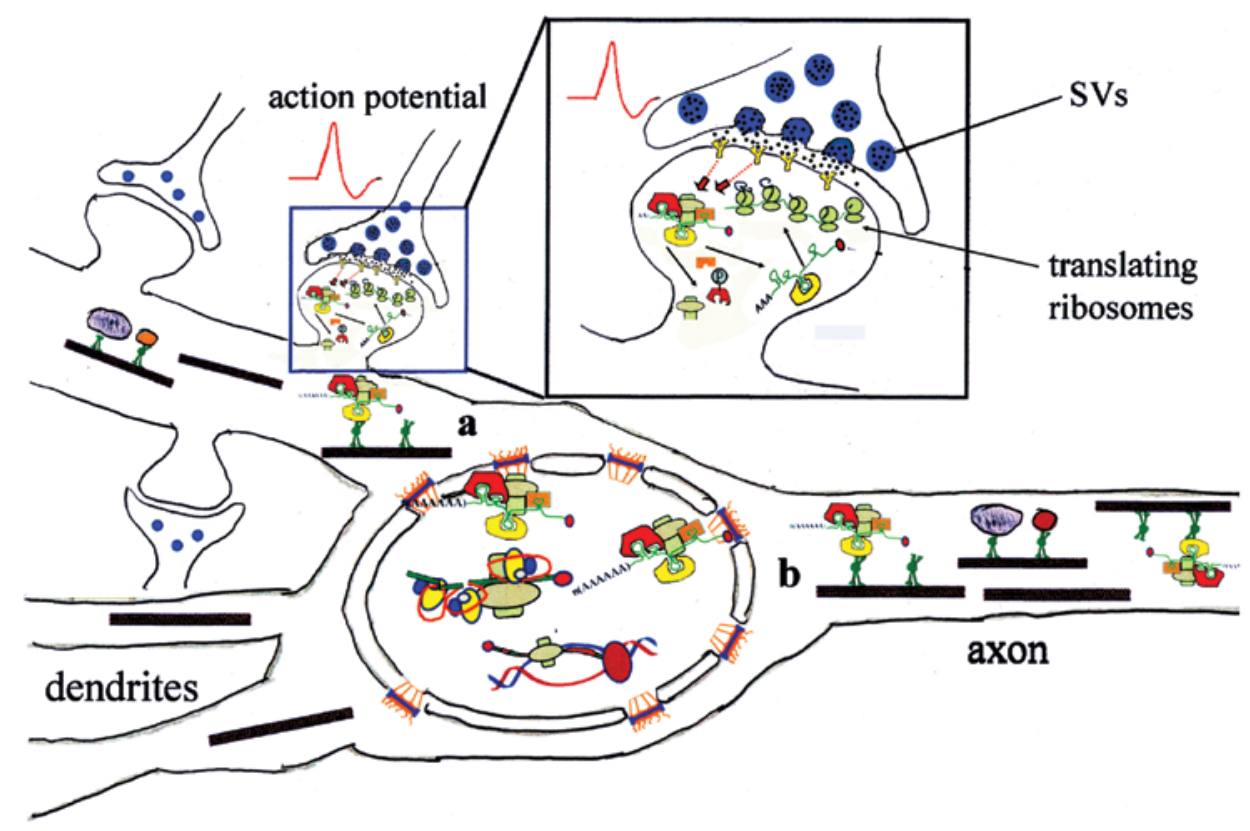

Figure 3. RNA traffic in neurons. As shown in Fig. 1, at the time of transcription, nascent RNA was already complexed with RNA-binding proteins (RBPs) to form RNA-protein particles (RNPs), which then migrate to the cytoplasm through the nuclear pore complex. In the cytoplasm, through interaction with motor proteins, RNPs are transported to their final destinations, where they can pause in a silent state, until they are activated by a signal. Some components of RNPs can then be cycled back to the nucleus. When exiting the nucleus, however, two different peripheral destinations are available to RNPs: a) dendrites or b) axon Localized translation of mRNA may be controlled by synaptic activity (action potential). In response to neurotransmitters and/or neuromodulators, which bind to their receptors on the post-synaptic element, signal transduction pathways can be activated (red dotted lines), which target RBPs, inducing post-translational modifications, such as phosphorylation. RBP modifications in turn cause remodelling of the RNPs, with the release of some RBPs and recruitment of mRNA to ribosomes. Newly synthesized proteins accumulate at the post-synaptic sites, thus inducing long-lasting modifications. SVs, neurotransmitter-containing synaptic vesicles. Synthesis, maturation, and transport of RNPs are shown as in Fig. 1.

expression. In this manner, responses to extracellular signals and neural activity may also be converted into a stable modification of the cell phenotype.

At least three major mechanisms are known for dynamic modification of chromatin organization: i) chromatin remodelling by ATP-dependent complexes (69); ii) post-translational modification of histone proteins (70), and iii) replacement of histone isotypes present in chromatin with other isotypes (71). During rat brain development, at least histones H3.3, a core histone variant, and $\mathrm{H}^{\circ}$, a linker histone variant, have been shown to accumulate during the terminal differentiation of nerve cells $(72,73)$, in the absence of gene activity changes. Post-transcriptional regulation of the expression of these two histones probably depends on the activity of a group of RNA-binding proteins $(74,49)$, some of which have been identified and cloned (75,76). Among these proteins, one was already known as Purkinje cell-expressed peptide (PEP-19, or PCP-4 in humans), but is also expressed in a neuron-specific manner in other brain regions $(77,78)$.

PEP-19 is a calmodulin-binding protein that is known to bind $\mathrm{H} 1^{\circ}$ mRNA (54). Similarly, PIPPin (also known as CSDC2) binds $\mathrm{H} 3.3$ and $\mathrm{H}^{\circ}$ mRNAs (49); it is a phosphoprotein that can be phosphorylated by different kinases (79, unpublished data), and that interacts with other proteins already known to bind RNA (50). It may therefore be hypothesized that, in response to calcium-dependent neuronal activity, proteins of this type are modified. Their post-translational modification may in turn change their interaction with histone variant mRNAs, thus inducing their translation and accumulation of the corresponding proteins. Histone variants could finally enter chromatin, thus modifying the structural organization and expression of specific genes.

\section{Messenger RNA trafficking and localization in neurons}

Mature transcripts can be localized through at least three mechanisms: i) local protection from degradation, ii) diffusion and local anchoring, and iii) direct transport by interaction with the cytoskeleton and cytoskeleton-associated motor proteins (80-82). Subcellular pre-localization of mRNAs and locally regulated translation offer cells at least three important advantages: i) energy saving: a high number of protein molecules can be obtained locally by transporting and translating a single mRNA molecule; ii) efficacy/safety of protein production: some proteins may be harmful to the cells when synthesized in the incorrect location; the myelin basic protein (MBP), a major component of the axon-wrapping myelin sheet, produced in the central nervous system (CNS) by oligodendrocytes, is, for example, a sticky protein that potentially interacts with any cell membrane if produced in the cell body $(12,83,84)$; other proteins, such as actin, tubulin and microtubule-associated proteins, exist as different isoforms, all able to form multimers/polymers; their localized synthesis allows the formation of only the right multimers; iii) differential translation regulation: in response to local signaling, proteins may be synthesized only in the compartment exposed to the signal $(85,86)$.

Pre-localization of mRNA is determined in polarized cells (87). The most asymmetric cells in the body are neurons, which consist of a cell body or soma, several branched dendrites 
and a long axon that can be 1,000-fold the diameter of the cell body (88). The most noteworthy property of nerve cells is the variety of morphologically different sub-compartments. Therefore, how a neuron, with only one cell nucleus and thus a single supply of active genes, obtains such a motley distribution of proteins if of interest and should be investigated.

$m R N A$ pre-localization in dendrites. Through utilization of different experimental approaches, such as in situ hybridization, and amplification of mRNAs present in neuronal processes, the presence in dendrites of a large number of mRNAs was clearly demonstrated. Among the dendritically localized messages the most intensively studied are those encoding microtubule-associated protein 2 (MAP2), the brain-derived neurotrophic factor, the $\alpha$ subunit of the calcium/calmodulin-dependent protein kinase II (CaMKII $\alpha$ ), the activity-regulated cytoskeleton-associated protein (Arc), the NMDAR NR1 subunit, and the AMPA receptor $(84,89,90)$. Dendritic RNA transport is specific and can be regulated by neuronal activity in a rapid manner $(91,92)$.

Information required for the successful mRNA transport to dendrites is sometimes contained in a single zipcode, as in the case of the non-protein coding, dendritically localized $\mathrm{BC} 1$ mRNA, which contains, at its 5'-end, a 62 nt zipcode, able to fold into a single stem-loop and to drive microtubule-dependent transport $(25,93-95)$. Other mRNAs have more complex localization signals. The MAP2 mRNA, for example, contains a $640 \mathrm{nt}$ zipcode element in its 3'-UTR, probably created with distinct sub-elements that fold into multiple stem-loops (96), and are able to mediate individual steps of RNP assembly and localization process. Similarly, the mRNA encoding the myelin basic protein in oligodendrocytes contains two distinct elements: i) A2RE, an $11 \mathrm{nt}$ element found only in transcripts that are localized (97); it forms the binding site for hnRNP A2 and is necessary and sufficient for transport $(98,99)$, and ii) a $1 \mathrm{~kb}$ long element, essential for appropriate localization of a protein-coding reporter RNA, and probably involved in RNA anchoring (25). Of note, the A2RE element was also identified in the neuronal mRNAs encoding CaMKII $\alpha$, Arc and neurogranin, all of which were assembled in the same granules containing hnRNP A2, and targeted to dendrites (100). Conversely, it has also been reported that the dendritically localized mRNAs encoding MAP2, CaMKII $\alpha$, and $\beta$-actin assemble in distinct RNPs, which contain very few RNA molecules $(101,102)$.

Besides positively acting elements, elements that inhibit transport also exist. Localization of CaMKII $\alpha$ depends on the 3'-UTR (103), which contains three positive cis-acting regions: i) a stretch of $\sim 1200 \mathrm{nt}$, in the latter half of the $3^{\prime}$-UTR, sufficient for localization (104); ii) one element present in the distal $170 \mathrm{nt}$ of the UTR, which contains cytoplasmic polyadenylation elements (CPEs) (105), and requires a wild-type CPE-binding protein (CPEB); iii) a third zipcode, within the first 94 nt of the 3'-UTR, which contains the already mentioned, 30-nt long sequence with high homology to an element present in neurogranin mRNA. Other elements in the CaMKII $\alpha$ mRNA, on the contrary, inhibit its transport, in the resting state, while inhibition is eliminated in the depolarized neurons as activity-dependent derepression is critical for their dendritic targeting (106).
Taken together, these findings suggest that assembly and transport of mRNAs involves different signals and highly specific RNA scanning by regulatory proteins. This complexity is likely at the origin of the several types of RNPs that have been described, such as transport RNPs, stress granules (SGs), processing bodies (P-bodies), and P-body-like structures (107-112). Composition of the complexes may vary with growth conditions, and different mRNA subsets are potentially present in different classes of particles; conversely, the same mRNA species may be found in multiple mRNP complexes. Based on these observations, Keene and Tenenbaum suggested that RBPs may regulate mRNAs as subpopulations during cell growth and development. Their model predicted that functionally related genes were regulated as groups or posttranscriptional operons, by specific mRNA-binding proteins that recognize sequence elements common among the mRNAs (113). One of these 'master' RBPs that controls the expression of several mRNAs at a time is the Fragile X mental retardation protein (FMRP), which regulates dendritic mRNA transport and local protein synthesis on the post-synaptic side of synapses. Over $400 \mathrm{mRNAs}$ have been reported to associate with FMRP. FMRP interacts with kinesins and is able to repress translation of its client mRNAs both in vitro and in vivo. More recently, FMRP has also been found in axons and growth cones, where it seems to be involved in responses induced by Semaphorin-3A (Sema3A) (114).

The specific interaction between RNAs and RBPs suggests the existence of an ' $R N A$ signature' that characterizes each transcript $(84,100)$. For example, the BC1 RNA assembles with proteins to form an RNP involved in the transport of dendritic mRNAs (93); the signal responsible for its dendritic targeting is a motif at its 5'-end, which folds into a single stem-loop instead of into a cloverleaf structure, as expected on the basis of its sequence similarity to tRNA. Notably, tRNAs also migrate to dendrites, but some of them remain and function in the cell body. It has been suggested that its structural properties allow BC1 RNA to be transported to dendrites more efficiently than tRNAs (94).

Further sources of cis-acting signal variability are alternative splicing and alternative polyadenylation site selection. These processes are capable of generating different RNA isoforms with different targeting specificities. In brain neurons, two distinct pools of brain-derived neurotrophic factor (BDNF) transcripts are produced by the differential use of polyadenylation sites, i.e., mRNA molecules with the longer 3'-UTR, but not those with the shorter one, contain localization elements, which target them to dendrites (115). At the same time, the longer 3'-UTR also mediates BDNF translation repression in the resting state and activity-dependent translation (116). In a recent study, it has been found that the longer 3'-UTR contains an AU-rich element (ARE) that interacts with the neuronal RBP HuD. Such an interaction is necessary and sufficient for the stabilization of the longer mRNA isoform (117).

A shorter and longer 3'-UTR species also exists in the case of CaMKII $\alpha$ mRNA, although the long mRNA is much more abundant. Again, the sequence required for dendritic targeting has been mapped downstream to the first polyadenylation site (104), suggesting that the shorter mRNA isoform is confined to the cell body, while the longer mRNA is transported to dendrites. It therefore seems that the strategy 
of alternative 3'-UTRs may be commonly adopted by genes encoding proteins with important functions in the cell body and dendrites.

As mentioned, cis-acting elements interact with RBPs that, by recognizing and binding them, control mRNA localization and stability and thus play an important role in the development and maintenance of the nervous system. Moreover, coordinated expression of neural genes may be obtained by assembly of their mRNAs in common mRNP complexes, which can contain different RBPs under different cell states and at different times (118). This process is of particular importance in modulating synaptic plasticity which seems to depend on the activity-induced translation of hundreds of locally targeted mRNAs, present in neuronal processes, where they drive a variety of specific functions (119).

For instance, mammalian zipcode-binding protein 1 (ZBP1) is required for the dendritic targeting of $\beta$-actin mRNA both in developing and mature neurons (120-122). Knockdown of ZBP1 in cultured hippocampal neurons reduced the dendritic levels of ZBP1 and $\beta$-actin mRNA and impaired the growth of dendritic filopodia in response to BDNF treatment (120). This observation is important when considering that the formation and density of dendritic filopodia during neuronal development are likely to be connected to the process of synaptogenesis (120,123-125). Phosphorylation of ZBP1, in response to extracellular signals such as BDNF, by the membrane-bound Src tyrosine kinase results in a decreased affinity of ZBP1 for its bound mRNA and consequent local activation of mRNA translation (126-128). However, only $\sim 50 \%$ of $\beta$-actin mRNA colocalizes with ZBP1 (92), thus suggesting the involvement of other RBPs in the localization/translation regulation of this mRNA. Another RBP required is the Src-associated with a mitosis of $68 \mathrm{kDa}$ (Sam68): knocking down Sam68 in neuronal cultures or interfering with its binding to $\beta$-actin mRNA causes a deficit of $\beta$-actin mRNA in dendrites and in spine density (122), while loss of Sam68 has been connected with the pathogenesis of neurodegenerative fragile $\mathrm{X}$ tremor/ataxia syndrome (FXTAS) $(129,130)$.

The zipcode-binding protein, ZBP2, was identified in chicken embryo brain by RNA affinity chromatography (through binding to an RNA fragment containing the zipcode) (131). ZBP2 is a predominantly nuclear protein that also affects $\beta$-actin mRNA localization in the cytoplasm; it is the chicken homologue of the human $\mathrm{KH}$ domain-containing splicing regulatory protein (KSRP), a protein involved in premRNA splicing (132). The homologue of ZBP2 in rat is the MAP2-RNA trans-acting protein (MARTA1), which binds the 3'-UTR of MAP2 mRNA, a dendritically localized neuronal transcript $(133,134)$. ZBP2 has been found to bind the nascent $\beta$-actin zipcode co-transcriptionally and to facilitate binding of ZBP1 to the zipcode (135). It provides an example of how interactions between RNA-binding proteins and RNA serve to recruit and stabilize additional proteins to form a large RNP.

Another well-studied factor involved in mRNA localization and, probably, modulation of translation is the already mentioned HnRNP A2 which binds MBP mRNA, allowing its correct localization in the oligodendrocyte processes in which myelination occurs (127). hnRNP F has been found to be a component of MBP transport granules, and to cooperate with HnRNP A2 in regulating MBP expression. Activity of this factor is controlled through phosphorylation by the Fyn kinase (136). HnRNP A2 was found in dendrites, in association with other hnRNPs, in large macromolecular complexes (neuronal transport granules) that contain mRNA, pre-mRNA splicing factors, and mRNA export factors (137). The presence of proteins with different roles in RBP granules is a common observation: for example, the complex responsible for dendritic targeting of a CaMKII reporter contains PSF (polypyrimidine tract-binding protein-associated splicing factor), hnRNPU and Staufen 1 RNA-binding proteins (127).

$m R N A$ pre-localization in axons. When discussing mRNA localization determinants in neurons, a challenging issue comes from the finding that mRNAs can be also localized in axons. For a long time, this possibility was not considered since the translational machinery did not seem to be present at significant levels in axons. Moreover, mechanisms ensuring protein transport from cell bodies to the axonal compartment were, on the contrary, present and efficient, thus making apparently unnecessary localized protein synthesis. However, findings of previous studies have demonstrated axonal localization and translation of several mRNA (138-144), including the $\beta$-actin mRNA (145-147), which depends on the zipcode recognized by ZBP1 for localization (148).

Together with $\beta$-actin transcript, mRNAs for which axonal localization has been reported include those for oxytocin and vasopressin $(149,150), \beta$-tubulin $(151)$, actin-depolymerizing factor ADF/cofilin (152), the microtubule-associated proteins $1 \mathrm{~b}$ (MAP1b) (153) and $\tau$ (154), the cytoskeleton regulating protein RhoA (155), the $\kappa$ opioid receptor (156) and heat shock proteins (157). Notably, among axonally localized mRNAs, transcripts encoding transcription factors have been found, an example being CREB mRNA (158). Moreover, after injury, the population of localized mRNA enlarges to include many transcripts encoding proteins of the translational apparatus and trans-membrane receptors (159). Thus, as with dendrites, a supply of mRNAs exists in axons, and some of these transcripts can be translated under special circumstances (160). In addition, the pool of axonal mRNAs markedly changes during development: in embryonic axons exclusively transcripts belonging to the 'cellular assembly and organization category' were found. These transcripts can be further subdivided into smaller subsets of cytoskeletalrelated mRNAs and transport of vesicles/trafficking-related mRNAs (161). These observations suggest that, at least in the growing axons, localized protein synthesis may allow dynamic remodelling of the axons during their progression through the extracellular environment.

Localization and translation of mRNA in axons still pose two main problems. The first one concerns the organization and regulation of the translational machinery: axoplasm structural domains have been recently described (periaxoplasmic ribosomal plaques: PARPs) which contain ribosomes attached to a superficial plaque-like structural matrix, together with $\beta$-actin mRNA, ZBP-1, SRP54, myosin Va and kinesin II molecular motor proteins. Rapid axoplasmic transport of microinjected heterologous radiolabeled BC1 RNA to putative PARP domains suggested that the anchored translation machinery potentially represents the destination of specifically sorted mRNAs (162). Moreover, multiple translation compo- 
nents, including ribosomal subunits and initiation factors, interact with the trans-membrane receptor (DCC) for netrin-1, suggesting that their activity can be regulated by extracellular signals (163). The possibility that ribosomes/mRNAs could be at least in part horizontally transferred into axons from surrounding glial cells was also discussed $(142,164)$. In addition, it has been reported that proximal segments of transected sciatic nerves accumulate newly synthesized RNA in axons, and that these mRNAs are actually synthesized in Schwann cells and then transferred to neurons through a mechanism that requires actin cytoskeleton and myosin-Va (165).

The second problem concerns specific transport to dendrites and/or axons for those mRNAs that use at least some identical zipcodes for both localizations. Preferential localization depends on the entire supply of RBPs assembled in a given RNP, including those necessary for anchoring RNPs to the cytoskeleton. Several aspects of microtubule organization, among which the specific microtubule-associated proteins (MAPs) and motor proteins, are different between axons and dendrites. These differences may be at the origin of specific sorting of cargoes and their differential targeting in neurons $(143,166)$.

\section{Locally regulated stabilization and/or translation of pre-localized mRNAs in neurogenesis}

General. Neurogenesis is an extremely complex, multi-step process through which self-renewing undifferentiated neural stem cells obtain different and integrated differentiated phenotypes (167). This process also occurs in the adult nervous system following ischemic insult or damage $(168,169)$, and has been implicated in learning, neuronal plasticity and memory formation in hippocampus $(170,171)$.

Regulation of mRNA metabolism during development. During development, neurons sprout processes or growth cones, which explore their environment and guide pathfinding over extremely long distances. It is now clear that at least some aspects of axon guidance require axonal mRNA translation (138-140,142-147). For example, Welshhans and Bassell developed and used a new in vitro turning assay allowing these authors to demonstrate that growth cones exhibit protein synthesis-dependent attraction to netrin-1 and BDNF. This attraction is lost in neurons lacking ZBP1; concomitantly, BDNF-induced $\beta$-actin mRNA localization is also attenuated. $\mathrm{ZBP} 1$ is also necessary for netrin-1-induced local translation of $\beta$-actin mRNA (148).

Responses of growth cone to guidance cues such as netrin-1, BDNF, and Sema3A proceed through cycles of desensitization and resensitization that are critical for navigation over large distances. Notably, in isolated growth cones, the resensitization step is eliminated by treatment with translation inhibitors, while the sensitization step is affected by inhibitors of endocytosis, but not by translation inhibitors $(160,172,173)$. Thus, only some steps of growth cone response to guidance cues require translation; when required, however, the activation of translation is triggered by signal transduction pathways which involve different kinases, including phosphatidylinositol3-kinase (PI3K), mammalian target of rapamycin (mTOR), and mitogen-activated kinases (MAPKs) $(160,174)$.
On the other hand, in the absence of induction signals, as well as during the translocation to mRNA final destinations, translation is inhibited. Some RBPs, such as ZBP1, block translation initiation by inhibiting recruitment of the $60 \mathrm{~S}$ subunit of the ribosome. In other cases, RBPs modulate the length of poly(A) tail $(174,175)$. Conversely, the cytoplasmic polyadenylation element-binding protein (CPEB) binds its recognition element (CPE) in the 3'-UTR of its target mRNAs and promotes polyadenylation-induced translation (176). Block of CPEB function in hippocampal neurons reduces the translation of $\beta$-catenin, induced in the growth cones by neurotrophin 3 (NT3), an effect that is probably mediated by calcium ions and CaMKII (177).

Translational regulation by RBPs can also be influenced by miRNAs; these latter molecules are capable of binding RBPs which are, in turn, able to regulate their abundance $(65,174,178-180)$. Several miRNAs are developmentally regulated in mammalian neurons and have been identified in axons $(181,182)$ and dendrites (65).

RBPs are expressed in region-specific patterns in developing brain, suggesting that they are crucial in the establishment of cell type-specific functions $(174,183)$. For example, the splicing regulator Rbfox1 (A2BP1), which may involved in the control of neuronal excitation and seizures, in the mammalian brain (184), is differentially expressed at different developmental stages and in different brain regions (185). In cortical neurons, A2BP1 accumulates in the nucleus, the cell body and dendrites, while in cultured hippocampal neurons it is mainly present in the nucleus but also evidenced in the proximity of synapses (185).

During cell division, asymmetric segregation of RBPs into one daughter cell also contributes to specify its fate, and to generate a cell lineage. For instance, it has been recently demonstrated that the RNA-binding protein Stau2 is asymmetrically distributed during progenitor divisions in the developing mouse cortex, thus determining the asymmetrical distribution of the mRNAs to which it binds $(186,187)$. In the radial glial precursor, Stau 2 forms a complex with other RBPs, such as Pumilio 2 (Pum2) and DEAD box 1 (DDX1), and with a number of mRNAs, including those encoding $\beta$-actin, mammalian prospero (prox1) (187), and the E3 ubiquitin ligase tripartite motif protein 32 (Trim32) (186). Perturbation of the complex induces premature differentiation of the radial glial precursors into neurons and mislocalization of the target mRNAs (187). Thus, it seems that asymmetric localization of RBPs can regulate the balance of stem cell maintenance versus cell differentiation, as well as cell fate.

Musashi-1 (Msi1) RBP was first reported to play a role in the development of the Drosophila adult external sensory organ (188). In mammals, Msil is considered a specific marker for neural/progenitor stem cells (189-193). It acts by suppressing translation of mRNAs encoding differentiation-inducing proteins, such as the membrane protein Numb which is involved in the Notch/Delta signalling cascade $(118,191,194,195)$, and the cyclin-dependent kinase inhibitor p21 ${ }^{\mathrm{WAF}-1}$ (196).

The embryonic lethal abnormal vision (ELAV)-like proteins form a highly conserved RNA-binding protein family, functionally involved in the stabilization of mRNAs which bear AU-rich elements (ARE). As with their Drosophila homologue, neuronal-specific proteins ELAV (nELAVL, originally 
$\mathrm{HuB}, \mathrm{HuC}$, and $\mathrm{HuD}$ ) are necessary and sufficient for inducing neuronal differentiation in mammalian neural precursors (197199) and are therefore considered markers of post-mitotic neurons (200). The nELAVL proteins were discovered through studies on paraneoplastic neurologic disorders (PND) (201). Some common tumors, such as small-cell lung, ovarian and breast cancers, produce proteins normally expressed in the nervous system; thus, the antitumor immune response is also directed against nerve cells, triggering neurologic symptoms (202). A number of reports have demonstrated that the overexpression of ELAVL proteins induces the stabilization of ARE-containing mRNAs. Ratti and colleagues found that nELAV proteins colocalize with, and bind to, Msil mRNA, in the adult mouse subventricular zone and in cultured neural stem/progenitor cells. They suggested that Msi1 and nELAV RNA-binding activities might be complementary and exert a different function on their target mRNAs. In other words, nELAV stabilization of the Msil transcript may prolong its expression during the gradual passage from proliferation to differentiation. This would allow the stem/progenitor cell to continue to divide even after Msil transcriptional inactivation (118). The post-transcriptional regulatory action of nELAV proteins on Msil mRNA seems to be evolutionarily restricted to mammals, and active from embryonic to adult neurogenesis. In adult neurogenic areas, nELAV activity might be transiently induced by spatial- and/or temporal-restricted signals. It has also been suggested that upregulation and cytoskeletal translocation of nELAV proteins, and the subsequent positive effects on Gap43 mRNA levels may be involved in synaptic plasticity and learning processes (see below), in the rat dentate gyrus $(203,204)$.

As mentioned, nELAV proteins are considered early markers of neuronal commitment and are expressed in a specific temporal order in the developing nervous system of vertebrates. In the adult mouse, specific patterns of expression of each nELAV member have been reported in different neuronal types, both in the central and peripheral nervous systems, thus suggesting a role of nELAV proteins in the maintenance of various types of postmitotic neurons: for instance, $\mathrm{HuC}$ is strongly expressed in all neurons of neocortex, while $\mathrm{HuD}$ is prevalent in the large projection cells of the internal pyramidal layer, and $\mathrm{HuB}$ is detectable only in scattered neurons $(205,206)$.

Of the target mRNAs regulated by the nELAV proteins some, in turn, encode proteins involved in mRNA metabolism, including mRNA which encodes the neuro-oncological ventral antigen 1 (Nova1) (207), a neuron-specific splicing factor that controls several mRNAs important for synaptic function by alternative maturation $(208,209)$. Nova1 mRNA stability and translation are positively controlled by nELAV proteins. Moreover, PKC-dependent nELAV phosphorylation induces the recruitment of Noval mRNA to polysomes (207). These findings suggest that, as in the case of transcription factors, a hierarchy of RNA-binding proteins exists whose members are expressed as part of a regulatory cascade.

Regulation of mRNA metabolism in learning and memory. The most noteworthy implication of locally regulated mRNA translation is its possible involvement in long-term changes that accompany the complex processes of learning and memory. Although $\mathrm{Hu}$ proteins were originally identified as early markers of neuronal differentiation (210), persistence of $\mathrm{HuB}, \mathrm{HuC}$ and $\mathrm{HuD}$ mRNAs in the adult nervous system, especially in the hippocampus and neocortex, indicates that they are also involved in adult neuronal plasticity and spatial learning $(200,204,211)$.

In mammals, HuD can form dimers and trimers that associate with bound mRNAs, with cytoskeleton proteins and with other ELAV-like proteins to form complexes (204) which, in turn, may associate with polysomes to form translationally competent complexes involved in learning (206) and in long-term memory storage and recall. The parallel increase of cytoskeleton proteins and HuD in the CA1 hippocampal region suggests a common mechanism of regulation.

A learning-specific increase of rodent nELAV proteins was demonstrated in both cell bodies and proximal dendrites of hippocampal pyramidal cells. Notably, the concomitant upregulation of $\mathrm{HuD}$ and GAP-43 expression, together with co-localization of $\mathrm{HuD}$ and GAP-43 mRNA, have been described in hippocampal pyramidal cells only in rodents that had learned two different spatial discrimination paradigms $(204,206)$. An effect of HuD in learning and memory has also been suggested by using human HuD-overexpressing mice, which do not show any motor/coordination deficits or apparent developmental abnormalities (212). Although HuD expression increases after learning, constitutive overexpression of this protein leads to deficits in behavioural tests such as contextual fear conditioning (CFC) and Morris water maze. These results suggest that $\mathrm{HuD}$ levels are tightly regulated and any alteration results in abnormal mRNA stabilization and cognitive impairment (212). Moreover, $\mathrm{HuD}$ is probably involved in the stabilization of GAP-43 in growth cones, where granules containing $\mathrm{HuD}$ also colocalize with GAP-43 mRNA and ribosomes present in these regions (213). HuD was found to be associated in vivo with large cytoplasmic granules in the neuronal cell body and smaller granules in dendrites. Both types of granules were also stained with the ribosomal marker Y10B, suggesting that they also contain ribosomes (203).

The nELAV proteins seem to represent the final target of a cellular cascade that involves PKC, and induces the downstream stabilization of specific mRNAs, implicated in memory trace formation (206). The role of PKC was confirmed in cultured hippocampal neurons, where phosphorylation of $\mathrm{HuD}$ regulates BDNF, NGF, NT-3 and GAP-43 mRNAs stability and protein expression. HuD was suggested to be negatively regulated by CARM1 methyl transferase, whose activity is controlled by PKC-dependent phosphorylation (214).

Besides nELAV proteins, which have been the most extensively studied RBPs, a few other proteins are involved in learning and memory. Iijima and colleagues, for instance, identified Hematopoietic Zinc Finger (Hzf), an RBP which regulates the dendritic localization of mRNAs in neuronal cells. This protein is highly expressed in Purkinje cells and binds to the 3'-UTR of type 1 inositol 1,4,5-trisphosphate receptor (IP3R1) mRNA. Post-transcriptional regulation by Hzf affects synaptic plasticity and motor learning in cerebellum, because $\mathrm{Hzf}^{-/}$mice exhibit severe impairments in motor coordination and motor learning related to cerebellar functions $(215,216)$. 
Obviously, the importance of RBP expression is paralleled by the importance of RNA cis-acting elements recognized by these proteins. Mutations in the 3'-UTR of mouse CamKII mRNA cause in vivo the disruption of dendritic localization and translation of CamKII $\alpha$, specifically affecting long-term memory formation, suggesting that CamKII $\alpha$ may be a component of the translation system necessary for memory consolidation (217).

\section{RBPs linked to human disease}

Considering their critical functions in development, it is not surprising that altered RNA protein interactions lead to severe pathologies, such as neurodegenerative diseases and complex neurologic syndromes. Fragile X syndrome (FXS), the most common form of inherited mental retardation, depends on mutation of a gene, located in the X chromosome, which encodes the already mentioned RNA-binding protein FMRP. Most clinical cases of FXS result from hyper-expansion and methylation of CGG repeats within the promoter of fmrl that cause deficit of its expression. FMRP is involved in the transport and translational regulation of several dendrite-localized mRNAs, including that encoding Arc $(218,219)$, a protein required for hippocampal long-term depression (LTD) and long-term potentiation (LTP) (220), and the amyloid precursor protein (APP) $(221,222)$, thus FMRP function is related to long-term synaptic plasticity. FMRP and its target mRNAs form granule-like complexes that are transported with a kinesin-dependent mechanism along microtubules (223).

Mice bearing a ko-fmrl gene show specific defects in trace fear memory and LTP loss in the anterior cingulate cortex and lateral amygdala, while retaining normal locomotion capacity and pain sensitivity (224). The interaction between fmrl and mGluR5, a Gp1 glutamate receptor, whose increased activity is one of the consequences of FMRP loss of function, was studied in mice bearing a ko version of fmrl, crossed with mice which showed a reduced mGluR5 expression. The results revealed that, in animals with $50 \%$ reduction of the activity of mGluR5, the symptoms of FXS were reduced, counterbalancing the defects caused by fmr1 mutation (225). The neuronal hyperexcitability linked to a lack of FMRP, which generates epileptogenic responses, resembles the effects of a lack of the already mentioned BC1 RNA, suggesting that BC RNAs and FMRP have similar and overlapping modes of action in translational repression at synapses (226).

FMRP deficiency was reported to affect the proliferation rate in cultured adult neural progenitor/stem cells (aNPCs), isolated from ko-fmrl mice. Moreover, mutated aNPCs have a higher tendency to differentiate into astrocytes as compared to aNPCs derived from normal brains. Notably, in mutated aNPCs, the Wnt signaling pathway as a whole is altered, and this alteration can be at the origin of the observed modification of cell differentiation balance (227). In vivo, deletion of FMRP from aNSCs leads to deficits in learning tasks that depend on adult hippocampal neurogenesis (228). Using ko-fmrl mice, a marked impairment of cognitive functions was demonstrated, accompanied by a decrease of post-synaptic proteins, and in particular the NMDA receptor, although the relationship between the two events has not yet been established (229).
Alterations similar to those observed in FMRP-mutated mice were also found in translin knockout mice. Similar to FMRP, translin is an RNA-binding protein that is able to associate with microtubules and motor proteins, and is involved in the transport and translation of mRNA localized in dendrites (230). Similarly, huntingtin $(\mathrm{Htt})$ and the Htt-associated protein 1 (HAP1) have been reported to be part of dendritic large transport granules which also contain microtubule-dependent motors and transport $\beta$-actin mRNA (109).

Another degenerative pathology that may involve altered RNA-protein interactions is frontotemporal lobar degeneration (FTLD). FTLD has been classified into two subtypes: i) the first one is characterized by accumulation of the microtubule-associated protein $\tau$ (FTLD- $\tau$ ) and ii) the second one is characterized by inclusion bodies that do not contain $\tau$, but contain ubiquitin (FTLD-U) (231). Recently, a major component of FTLD-U inclusion bodies has been identified as TAR DNA-binding protein-43 (TDP-43), a protein of 43 amino acids encoded on chromosome 1, that can bind both DNA and RNA and functions as a splicing factor. Besides FTLD, amyotrophic lateral sclerosis (ALS) and other related neurodegenerative disorders show inclusions of TDP-43 and are now known as TDP-43 proteinopathies (232). TDP-43 extracted from tissues of FTLD or ALS is often hyperphosphorylated, ubiquitinated and poorly soluble (231). Of note, several mutations in ALS have been found in the gene encoding angiogenin (ANG), a secreted RNase (233). Angiogenin and TDP-43 have been identified in stress granules, assemblies of different RBPs and mRNAs. Moreover, angiogenin stimulates the transcription of rRNA and is responsible for the production of stress-induced small RNAs (234). As mentioned in a previous section, TDP-43 has also been found in ribonucleoprotein complexes, which also contain Stau and FMRP (38).

As a final example, proximal spinal muscular atrophy (SMA) is an autosomal recessive disease caused by alteration of the Smn1 gene, that encodes SMN, a protein present in the cells as part of a complex which also contains Sm proteins and U snRNAs, the core components of the pre-mRNA splicing machinery. Recently, it has been reported that KH-type splicing regulatory protein (KSRP), a multifunctional protein closely related to chick ZBP2 and rat MARTA 1, and involved in the exosome-mediated degradation of ARE-containing mRNAs, interacts with SMN. This interaction is lost in the naturally occurring mutations of SMN, found in Type 1 SMA patients (235). Another partner of SMN is the ribonucleoprotein-R (hnRNPR), a protein involved in the axonal transport of $\beta$-actin mRNA. Loss of $\beta$-actin mRNA in axonal growth cones of hnRNPR-depleted motor neurons resembles the condition observed in SMN-deficient motor neurons (236).

\section{Conclusion and future directions}

As reviewed in the previous sections, a number of studies have previously clearly demonstrated the importance of mRNA localization and the regulated translation in neuronal functions ranging from axon pathfinding in development to nerve regeneration in the adult nervous system, as well as in the long-lasting changes involved in learning and memory. 
However, a number of issues remain to be resolved. It is, for example, still uncertain whether and how mRNAs are actually anchored in the active sites of cell processes, e.g., whether silent RNPs are stably associated with specific synapses. An interesting model has been proposed by Doyle and Kiebler (84), who suggested that RNPs containing the mRNAs necessary, for example, for specialized dendritic functions are not strictly anchored in a single site but, instead, continuously move, patrolling groups of synapses in dendrites. RNPs should then be specifically captured and modified in order to allow translation of the cargo mRNAs only from sites in which synaptic activity is high. They named their model 'sushi belt model', after the conveyor belt used in most Japanese sushi restaurants: the belt conveys sushi to all the potential consumers; however, the hungriest ones consume more items. In the same manner, synapses recently activated should be 'hungrier' than silent ones and are likely to capture/modify RNPs (84).

The most puzzling question is how a given mRNA is specifically delivered to dendrites (pathway 'a' in Fig. 3) or to the axon (pathway 'b' in Fig. 3). The microtubule-associated proteins MAP2 and $\tau$ are enriched in dendrites and axons, respectively; however, it remains to be determined whether these and/or other cytoskeleton-associated proteins have a role in selecting RNPs. As mRNAs already associate with some RBPs in the nucleus, whether RNA final destination have been decided from the beginning remains to be clarified, and if this occurs specificity factors should be found among nuclear proteins.

It seems that glial cells are involved in regulating localized translation in axons, through the horizontal transfer of ribosomes (142). An attractive working hypothesis can thus be that glial cells also transfer into neurons regulatory factors, including transcription factors and RBPs, by sorting them to membrane microvesicles and/or to exosomes, which are then shed from glial cells and fuse with neuronal plasma membranes, delivering their cargoes into nerve cells.

It also remains to be defined how miRNA and RBPs cooperate in regulating mRNA metabolism in neurons. In these latter cells, ncRNAs may have an additional role in mRNA silencing during transport and storage processes. In conclusion, mRNAs, miRNAs and RBPs form dynamic complexes in which part of the components probably have only structural functions, while others confer upon mRNA the ability to be specifically sorted to a given sub-cellular compartment and/or to be translated in response to extracellular signals. In other words, RNPs may be regarded as 'mobile nucleosomes', possibly originating from an ancient RNA world.

\section{Acknowledgements}

The authors have been supported by the Università degli Studi di Palermo, Palermo, Italy.

\section{References}

1. Mauger DM, Siegfried NA and Weeks KM: The genetic code as expressed through relationships between mRNA structure and protein function. FEBS Lett 587: 1180-1188, 2013.

2. Thapar R and Denmon AP: Signaling pathways that control mRNA turnover. Cell Signal 25: 1699-1710, 2013.

3. Will CL and Lührmann R: Spliceosome structure and function. Cold Spring Harb Perspect Biol 3: pii: a003707, 2011.
4. Chiou NT, Shankarling G and Lynch KW: hnRNP L and hnRNP A1 induce extended U1 snRNA interactions with an exon to repress spliceosome assembly. Mol Cell 49: 972-982, 2013.

5. Suzuki H, Kameyama T, Ohe K, Tsukahara T and Mayeda A Nested introns in an intron: evidence of multi-step splicing in a large intron of the human dystrophin pre-mRNA. FEBS Lett 587: 555-561, 2013.

6. Sasaki-Haraguchi N, Shimada MK, Taniguchi I, Ohno M and Mayeda A: Mechanistic insights into human pre-mRNA splicing of human ultra-short introns: potential unusual mechanism identifies G-rich introns. Biochem Biophys Res Commun 423: 289-294, 2012.

7. Matsumoto K, Wassarman KM and Wolffe AP: Nuclear history of a pre-mRNA determines the translational activity of cytoplasmic mRNA. EMBO J 17: 2107-2121, 1998.

8. Stewart M: Nuclear export of mRNA. Trends Biochem Sci 35: 609-617, 2010.

9. Ramos A, Gubser CC and Varani G: Recent solution structures of RNA and its complexes with drugs, peptides and proteins. Curr Opin Struct Biol 7: 317-323, 1997.

10. Linder P and Tuite MF: The versatility of RNA structure and function. Jacques Monod Conference: New insights into the mechanism of mRNA translation: the significance of RNA structure, Aussois, France, 22-26 March 1999. Trends Genet 15: 302-303, 1999.

11. Caprara MG and Nilsen TW: RNA: versatility in form and function. Nat Struct Biol 7: 831-833, 2000.

12. Derrigo M, Cestelli A, Savettieri G and Di Liegro I: RNA-protein interactions in the control of stability and localization of messenger RNA (Review). Int J Mol Med 5: 111-123, 2000.

13. Butcher SE and Pyle AM: The molecular interactions that stabilize RNA tertiary structure: RNA motifs, patterns, and networks. Acc Chem Res 44: 1302-1311, 2011.

14. Hajdin CE, Bellaousov S, Huggins W, Leonard CW, Mathews DH and Weeks KM: Accurate SHAPE-directed RNA secondary structure modeling, including pseudoknots. Proc Natl Acad Sci USA 110: 5498-5503, 2013.

15. Doetsch M, Schroeder R and Fürtig B: Transient RNA-protein interactions in RNA folding. FEBS J 278: 1634-1642, 2011.

16. Weeks KM: Protein-facilitated RNA folding. Curr Opin Struct Biol 7: 336-342, 1997.

17. Liu L and Chen SJ: Coarse-grained prediction of RNA loop structures. PLoS One 7: e48460, 2012.

18. Fuller-Pace FV: RNA helicases: modulators of RNA structure. Trends Cell Biol 4: 271-274, 1994.

19. De la Cruz J, Kressler D and Linder P: Unwinding RNA in Saccharomyces cerevisiae: DEAD-box, proteins and related families. Trends Biochem Sci 24: 192-198, 1999.

20. Linder P: mRNA export: RNP remodeling by DEAD-box proteins. Curr Biol 18: R297-R299, 2008.

21. Herschlag D: RNA chaperones and the RNA folding problem. J Biol Chem 270: 20871-20874, 1995.

22. Clodi E, Semrad K and Schroeder R: Assaying RNA chaperone activity in vivo using a novel folding trap. EMBO J 18: 3776-3782, 1999.

23. Grohman JK, Gorelick RJ, Lickwar CR, Lieb JD, Bower BD, Znosko BM and Weeks KM: A guanosine-centric mechanism for RNA chaperone function. Science 340: 190-195, 2013.

24. Kislauskis EH and Singer RH: Determinants of mRNA localization. Curr Opin Cell Biol 4: 975-978, 1992.

25. Jambhekar A and Derisi JL: Cis-acting determinants of asymmetric, cytoplasmic RNA transport. RNA 13: 625-642, 2007.

26. Lunde BM, Moore $\mathrm{C}$ and Varani G: RNA-binding proteins: modular design for efficient function. Nat Rev Mol Cell Biol 8: 479-490, 2007.

27. Doyle M and Kiebler MA: A zipcode unzipped. Genes Dev 26: 110-113, 2012.

28. Dienstbier M, Boehl F, Li X and Bullock SL: Egalitarian is a selective RNA-binding protein linking mRNA localization signals to the dynein motor. Genes Dev 23: 1546-1558, 2009.

29. Patel VL, Mitra S, Harris R, Buxbaum AR, Lionnet T, Benowitz M, Girvin M, Levy M, Almo SC, Singer RH and Chao JA: Spatial arrangement of an RNA zipcode identifies mRNAs under posttranscriptional control. Genes Dev 26: 43-53, 2012.

30. Chao JA, Patskovsky Y, Patel V, Levy M, Almo SC and Singer RH: ZBP1 recognition of $\beta$-actin zipcode induces RNA looping. Genes Dev 24: 148-158, 2010.

31. Burd CG and Dreyfuss G: Conserved structures and diversity of functions of RNA-binding proteins. Science 265: 615-621, 1994. 
32. Siomi H, Matunis MJ, Michael WM and Dreyfuss G: The pre-mRNA binding $\mathrm{K}$ protein contains a novel evolutionary conserved motif. Nucleic Acids Res 21: 1193-1198, 1993.

33. St Johnston D, Benchle D and Nusslein-Volhard C: Staufen, a gene required to localize maternal RNAs in the Drosophila egg. Cell 66: 51-63, 1991.

34. Dubnau J, Chiang AS, Grady L, Barditch J, Gossweiler S, McNeil J, Smith P, Buldoc F, Scott R, Certa U, Broger C and Tully T: The staufen/pumilio pathway is involved in Drosophila long-term memory. Curr Biol 13: 286-296, 2003.

35. Liu J, Hu JY, Wu F, Schwartz JH and Schacher S: Two mRNAbinding proteins regulate the distribution of syntaxin mRNA in Aplysia sensory neurons. J Neurosci 26: 5204-5214, 2006.

36. Furic L, Maher-Laporte M and DesGroseillers L: A genome-wide approach identifies distinct but overlapping subsets of cellular mRNAs associated with Staufen1- and Staufen2-containing ribonucleoprotein complexes. RNA 14: 324-335, 2008.

37. Lebeau G, DesGroseillers L, Sossin W and Lacaille JC: mRNA binding protein staufen 1-dependent regulation of pyramidal cell spine morphology via NMDA receptor-mediated synaptic plasticity. Mol Brain 4: 22, 2011

38. Yu Z, Fan D, Gui B, Shi L, Xuan C, Shan L, Wang Q, Shang Y and Wang Y: Neurodegeneration-associated TDP-43 interacts with fragile $\mathrm{X}$ mental retardation protein (FMRP)/Staufen (STAU1) and regulates SIRT1 expression in neuronal cells. J Biol Chem 287: 22560-22572, 2012.

39. Ravasi T, Huber T, Zavolan M, Forrest A, Gaasterland T, Grimmond S, Hume DA; RIKEN GER Group; GSL Members: Systematic characterization of the zinc-finger-containing proteins in the mouse transcriptome. Genome Res 13: 1430-1442, 2003.

40. Brown RS: Zinc finger proteins: getting a grip on RNA. Curr Opin Struct Biol 15: 94-98, 2005.

41. Xu B and Koenig RJ: An RNA-binding domain in the thyroid hormone receptor enhances transcriptional activation. J Biol Chem 279: 33051-33056, 2004

42. Dominski Z, Erkmann JA, Yang X, Sanchez R and Marzluff WF: A novel zinc finger protein is associated with U7 snRNP and interacts with the stem-loop binding protein in the histone pre-mRNP to stimulate 3'-end processing. Genes Dev 16: 58-71, 2002.

43. Brewer BY, Malicka J, Blackshear PJ and Wilson GM: RNA sequence elements required for high affinity binding by the zinc finger domain of tristetraprolin: conformational changes coupled to the bipartite nature of AU-rich mRNA-destabilizing motifs. J Biol Chem 279: 27870-27877, 2004.

44. Sanduja S, Blanco FF and Dixon DA: The roles of TTP and BRF proteins in regulated mRNA decay. Wiley Interdiscip Rev RNA 2: 42-57, 2011

45. Carballo E, Lai WS and Blackshear PJ: Feedback inhibition of macrophage tumor necrosis factor- $\alpha$ production by tristetraprolin. Science 281: 1001-1005, 1998.

46. Miroci H, Schob C, Kindler S, Ölschläger-Schütt J, Fehr S, Jungenitz T, Schwarzacher SW, Bagni C and Mohr E: Makorin ring zinc finger protein 1 (MKRN1), a novel poly(A)-binding protein-interacting protein, stimulates translation in nerve cells. J Biol Chem 287: 1322-1334, 2012.

47. Grauman PL and Marahiel MA: A superfamily of proteins that contain the cold-shock domain. Trends Biochem Sci 23: 286-290, 1998.

48. Matsumoto K, Meric F and Wolffe AP: Translational repression dependent on the interaction of the Xenopus Y-box Protein FRGY2 with mRNA. Role of the cold shock domain, tail domain, and selective RNA sequence recognition. J Biol Chem 271: 22706-22712, 1996

49. Nastasi T, Scaturro M, Bellafiore M, Raimondi L, Beccari S, Cestelli A and Di Liegro I: PIPPin is a brain-specific protein that contains a cold-shock domain and binds specifically to $\mathrm{H} 1$ degrees and H3.3 mRNAs. J Biol Chem 274: 24087-24093, 1999.

50. Di Liegro CM, Schiera G, Proia P, Saladino P and Di Liegro I: Identification in the rat brain of a set of nuclear proteins interacting with $\mathrm{H} 1^{\circ}$ mRNA. Neuroscience 229: 71-76, 2013

51. Chu E and Allegra CJ: The role of thymidylate synthase as an RNA binding protein. Bioessays 18: 191-198, 1996.

52. Preiss T, Chrzanowska-Lightowlers ZM and Lightowlers RN: Glutamate dehydrogenase: an organelle-specific mRNA-binding protein. Trends Biochem Sci 22: 290, 1997

53. Zhou Y, Yi X, Stoffer JB, Bonafe N, Gilmore-Hebert M, McAlpine J and Chambers SK: The multifunctional protein glyceraldehyde-3-phosphate dehydrogenase is both regulated and controls colony-stimulating factor-1 messenger RNA stability in ovarian cancer. Mol Cancer Res 6: 1375-1384, 2008
54. Saladino P, Di Liegro CM, Proia P, Sala A, Schiera G, Lo Cicero A and Di Liegro I: RNA-binding activity of the rat calmodulinbinding PEP-19 protein and of the long PEP-19 isoform. Int J Mol Med 29: 141-145, 2012.

55. He L and Hannon GJ: MicroRNAs: small RNAs with a big role in gene regulation. Nat Rev Genet 5: 522-531, 2004.

56. Krol J, Loedige I and Filipowicz W: The widespread regulation of microRNA biogenesis, function and decay. Nat Rev Genet 11: 597-610, 2010.

57. Bartel B: MicroRNAs: target recognition and regulatory functions. Cell 136: 215-233, 2009.

58. Fabian MR and Sonenberg N: The mechanics of miRNAmediated gene silencing: a look under the hood of miRISC. Nat Struct Mol Biol 19: 586-593, 2012.

59. Mendell JT: MicroRNAs: critical regulators of development, cellular physiology and malignancy. Cell Cycle 4: 1179-1184, 2005.

60. Esquela-Kerscher A and Slack FJ: Oncomirs - microRNAs with a role in cancer. Nat Rev Cancer 6: 259-269, 2006.

61. Croce CM: Causes and consequences of microRNA dysregulation in cancer. Nat Rev Genet 10: 704-714, 2009.

62. Esteller M: Non-coding RNAs in human disease. Nat Rev Genet 12: 861-874, 2011 .

63. Ciafrè $\mathrm{S}$ and Galardi S: MicroRNAs and RNA-binding proteins: a complex network of interactions and reciprocal regulations in cancer. RNA Biol 10: 935-942, 2013.

64. Kosik KS and Krichevsky AM: The elegance of the microRNAs: a neuronal perspective. Neuron 47: 779-782, 2005.

65. Schratt GM, Tuebing F, Nigh EA, Kane CG, Sabatini ME, Kiebler $M$ and Greenberg ME: A brain-specific microRNA regulates dendritic spine development. Nature 439: 283-289, 2006

66. Im HI and Kenny PJ: MicroRNAs in neuronal function and disfunction. Trends Neurosci 35: 325-334, 2012.

67. Lee SR and Lykke-Andersen J: Emerging roles for ribonucleoprotein modification and remodelling in controlling RNA fate. Trends Cell Biol 23: 504-510, 2013.

68. Paquin $\mathrm{N}$ and Chartrand P: Local regulation of mRNA translation: new insights from the bud. Trends Cell Biol 18: 105-111, 2008

69. Struhl K and Segal E: Determinants of nucleosome positioning. Nat Struct Mol Biol 20: 267-273, 2013.

70. Paul S and Knott JG: Epigenetic control of cell fate in mouse blastocysts: the role of covalent histone modifications and chromatin remodeling. Mol Reprod Dev: Jul 24, 2013 (Epub ahead of print).

71. Szenker E, Ray-Gallet D and Almouzni G: The double face of the histone variant H3.3. Cell Res 21: 421-434, 2011.

72. Castiglia D, Cestelli A, Scaturro M, Nastasi T and Di Liegro I: $\mathrm{H} 1(0)$ and $\mathrm{H} 3.3 \mathrm{~B}$ mRNA levels in developing rat brain. Neurochem Res 19: 1531-1537, 1994.

73. Scaturro M, Cestelli A, Castiglia D, Nastasi T and Di Liegro I: Posttranscriptional regulation of $\mathrm{H} 1$ zero and $\mathrm{H} 3.3 \mathrm{~B}$ histone genes in differentiating rat cortical neurons. Neurochem Res 20: 969-976, 1995.

74. Scaturro M, Nastasi T, Raimondi L, Bellafiore M, Cestelli A and Di Liegro I: H1(0) RNA-binding proteins specifically expressed in the rat brain. J Biol Chem 273: 22788-22791, 1998.

75. Castiglia D, Scaturro M, Nastasi T, Cestelli A and Di Liegro I: PIPPin, a putative RNA-binding protein specifically expressed in the rat brain. Biochem Biophys Res Commun 218: 390-394, 1996.

76. Sala A, Scaturro M, Proia P, Schiera G, Balistreri E, Aflalo-Rattenbach R, Créau N and Di Liegro I: Cloning of a ratspecific long PCP4/PEP19 isoform. Int J Mol Med 19: 501-509, 2007.

77. Ziai R, Pan YC, Hulmes JD, Sangameswaran L and Morgan JI: Isolation, sequence, and developmental profile of a brain-specific polypeptide, PEP-19. Proc Natl Acad Sci USA 83: 8420-8423, 1986.

78. Slemmon JR, Morgan JI, Fullerton SM, Danho W, Hilbush BS and Wengenack TM: Camstatins are peptide antagonists of calmodulin based upon a conserved structural motif in PEP-19, neurogranin, and neuromodulin. J Biol Chem 271: 15911-15917, 1996.

79. Auld GC, Campbell DG, Morrice N and Cohen P: Identification of calcium-regulated heat-stable protein of $24 \mathrm{kDa}$ (CRHSP24) as a physiological substrate for PKB and RSK using KESTREL. Biochem J 389: 775-783, 2005

80. St Johnston D: Moving messages: the intracellular localization of mRNAs. Nat Rev Mol Cell Biol 6: 363-375, 2005.

81. Palacios IM: How does an mRNA find its way? Intracellular localisation of transcripts. Semin Cell Dev Biol 18: 163-170, 2007.

82. Gonsalvez GB and Long RM: Spatial regulation of translation through RNA localization. F1000 Biol Rep 4: 16, 2012. 
83. St Johnston D: The intracellular localization of messenger RNAs. Cell 81: 161-170, 1995.

84. Doyle $\mathrm{M}$ and Kiebler MA: Mechanisms of dendritic mRNA transport and its role in synaptic tagging. EMBO J 30: 3540-3552, 2011.

85. Andreassi C and Riccio A: To localize or not to localize: mRNA fate is in 3'UTR ends. Trends Cell Biol 19: 465-474, 2009.

86. Jung H, Yoon BC and Holt CE: Axonal mRNA localization and local protein synthesis in nervous system assembly, maintenance and repair. Nat Rev Neurosci 13: 308-324, 2012.

87. Holt CE and Bullock SL: Subcellular mRNA localization in animal cells and why it matters. Science 326: 1212-1216, 2009

88. Donnelly CJ, Fainzilber M and Twiss JL: Subcellular communication through RNA transport and localized protein synthesis. Traffic 11: 1498-1505, 2010

89. Eberwine J, Miyashiro K, Kacharmina JE and Job C: Local translation of classes of mRNAs that are targeted to neuronal dendrites. Proc Natl Acad Sci USA 98: 7080-7085, 2001.

90.Grooms SY, Noh KM, Regis R, Bassell GJ, Bryan MK, Carroll RC and Zukin RS: Activity bidirectionally regulates AMPA receptor mRNA abundance in dendrites of hippocampal neurons. J Neurosci 26: 8339-8351, 2006.

91. Rook MS, Lu M and Kosik KS: CaMKIIalpha 3' untranslated region-directed mRNA translocation in living neurons: visualization by GFP linkage. J Neurosci 20: 6385-6393, 2000.

92. Tiruchinapalli DM, Oleynikov Y, Kelic S, Shenoy SM, Hartley A, Stanton PK, Singer RH and Bassell GJ: Activity-dependent trafficking and dynamic localization of zipcode binding protein 1 and beta-actin mRNA in dendrites and spines of hippocampal neurons. J Neurosci 23: 3251-3261, 2003.

93. Muslimov IA, Santi E, Homel P, Perini S, Higgins D and Tiedge H: RNA transport in dendrites: a cis-acting targeting element is contained within neuronal BC1 RNA. J Neurosci 17: 4722-4733, 1997.

94. Rozhdestvensky TS, Kopylov AM, Brosius J and Hüttenhofer A: Neuronal BC1 RNA structure: evolutionary conversion of a tRNA(Ala) domain into an extended stem-loop structure. RNA 7: 722-730, 2001

95. Cristofanilli M, Iacoangeli A, Muslimov IA and Tiedge $\mathrm{H}$ Neuronal BC1 RNA: microtubule-dependent dendritic delivery. J Mol Biol 356: 1118-1123, 2006.

96.Blichenberg A, Schwanke B, Rehbein M, Garner CC, Richter D and Kindler S: Identification of a cis-acting dendritic targeting element in MAP2 mRNAs. J Neurosci 19: 8818-8829, 1999.

97. Ainger K, Avossa D, Diana AS, Barry C, Barbarese E and Carson JH: Transport and localization elements in myelin basic protein mRNA. J Cell Biol 138: 1077-1087, 1997.

98. Hoek KS, Kidd GJ, Carson JH and Smith R: hnRNP A2 selectively binds the cytoplasmic transport sequence of myelin basic protein mRNA. Biochemistry 37: 7021-7029, 1998.

99. Munro TP, Magee RJ, Kidd GJ, Carson JH, Barbarese E, Smith LM and Smith R: Mutational analysis of a heterogeneous nuclear ribonucleoprotein A2 response element for RNA trafficking. J Biol Chem 274: 34389-34395, 1999.

100.Gao Y, Tatavarty V, Korza G, Levin MK and Carson JH: Multiplexed dendritic targeting of alpha calcium calmodulindependent protein kinase II, neurogranin, and activity-regulated cytoskeleton-associated protein RNAs by the A2 pathway. Mol Biol Cell 19: 2311-2327, 2008.

101. Mikl M, Vendra G and Kiebler MA: Independent localization of MAP2, CaMKII $\alpha$ and $\beta$-actin RNAs in low copy numbers EMBO Rep 12: 1077-1084, 2011.

102.Tübing F, Vendra G, Mikl M, Macchi P, Thomas S and Kiebler MA: Dendritically localized transcripts are sorted into distinct ribonucleoprotein particles that display fast directional motility along dendrites of hippocampal neurons. J Neurosci 30 4160-4170, 2010.

103. Mayford M, Baranes D, Podsypanina K and Kandel ER: The 3'-untranslated region of CaMKII alpha is a cis-acting signal for the localization and translation of mRNA in dendrites. Proc Natl Acad Sci USA 93: 13250-13255, 1996.

104. Blichenberg A, Rehbein M, Muller R, Garner CC, Richter D and Kindler S: Identification of a cis-acting dendritic targeting element in the mRNA encoding the alpha subunit of $\mathrm{Ca}^{2+}$ calmodulin-dependent protein kinase II. Eur J Neurosci 13: 1881-1888, 2001.

105. Huang YS, Carson JH, Barbarese E and Richter JD: Facilitation of dendritic mRNA transport by CPEB. Genes Dev 17: 638-653, 2003.
106. Mori Y, Imaizumi K, Katayama T, Yoneda T and Tohyama M Two cis-acting elements in the 3 ' untranslated region of alphaCaMKII regulate its dendritic targeting. Nat Neurosci 3 : 1079-1084, 2000

107.Zeitelhofer M, Macchi P and Dahm R: Perplexing bodies: the putative roles of P-bodies in neurons. RNA Biol 5: 244-248, 2008

108. Miller LC, Blandford V, McAdam R, Sanchez-Carbente MR, Badeaux F, DesGroseillers L and Sossin WS: Combinations of DEAD box proteins distinguish distinct types of RNA: protein complexes in neurons. Mol Cell Neurosci: 40: 485-495, 2009.

109. Ma B, Savas JN, Yu MS, Culver BP, Chao MV and Tanese N Huntingtin mediates dendritic transport of $\beta$-actin mRNA in rat neurons. Sci Rep 1: 140, 2011.

110. Batista PJ and Chang HY: Cytotopic localization by long noncoding RNAs. Curr Opin Cell Biol 25: 195-199, 2013.

111. Lloyd RE: Regulation of stress granules and P-bodies during RNA virus infection. Wiley Interdiscip Rev RNA 4: 317-331, 2013.

112. Oh JY, Kwon A, Jo A, Kim H, Goo YS, Lee JA and Kim HK: Activity-dependent synaptic localization of processing bodies and their role in dendritic structural plasticity. J Cell Sci 126 2114-2123, 2013

113. Keene JD and Tenenbaum SA: Eukaryotic mRNPs may represent posttranscriptional operons. Mol Cell 9: 1161-1167, 2002.

114. Li C, Bassell GJ and Sasaki Y: Fragile X mental retardation protein is involved in protein synthesis-dependent collapse of growth cones induced by semaphorin-3A. Front Neural Circuits 3: 11, 2009

115. An JJ, Gharami K, Liao GY, Woo NH, Lau AG, Vanevski F, Torre ER, Jones KR, Feng Y, Lu B and Xu B: Distinct role of long 3' UTR BDNF mRNA in spine morphology and synaptic plasticity in hippocampal neurons. Cell 134: 175-187, 2008.

116. Lau AG, Irier HA, Gu J, Tian D, Ku L, Liu G, Xia M, Fritsch B, Zheng JQ, Dingledine R, Xu B, Lu B and Feng Y: Distinct 3'UTRs differentially regulate activity-dependent translation of brain-derived neurotrophic factor (BDNF). Proc Natl Acad Sci USA 107: 15945-15950, 2010.

117. Allen M, Bird C, Feng W, Liu G, Li W and Perrone-Bizzozero NI: $\mathrm{HuD}$ promotes BDNF expression in brain neurons via selective stabilization of the BDNF long 3'UTR mRNA. PLoS One 8: e55718, 2013.

118. Ratti A, Fallini C, Cova L, Fantozzi R, Calzarossa C, Zennaro E, Pascale A, Quattrone A and Silani V: A role for the ELAV RNA-binding proteins in neural stem cells: stabilization of Msi1 mRNA. J Cell Sci 119: 1442-1452, 2006.

119. Martin KC and Ephrussi A: mRNA localization: gene expression in the spatial dimension. Cell 136: 719-730, 2009.

120. Eom T, Antar LN, Singer RH and Bassell GJ: Localization of a beta-actin messenger ribonucleoprotein complex with zipcodebinding protein modulates the density of dendritic filopodia and filopodial synapses. J Neurosci 23: 10433-10444, 2003.

121. Perycz M, Urbanska AS, Krawczyk PS, Parobczak K and Jaworski J: Zipcode binding protein 1 regulates the development of dendritic arbors in hippocampal neurons. J Neurosci 31 5271-5285, 2011

122. Klein ME, Younts TJ, Castillo PE and Jordan BA: RNA-binding protein Sam68 controls synapse number and local $\beta$-actin mRNA metabolism in dendrites. Proc Natl Acad Sci USA 110 3125-3130, 2013

123. Cooper MW and Smith SJ: A real time analysis of growth cone target cell interactions during the formation of stable contacts between hippocampal neurons in culture. J Neurobiol 23: 814-828, 1992

124.Ziv NE and Smith SJ: Evidence for a role of dendritic filopodia in synaptogenesis and spine formation. Neuron 17: 91-102, 1996

125. Fiala JC, Feinberg M, Popov V and Harris KM: Synaptogenesis via dendritic filopodia in developing hippocampal area CA1 J Neurosci 18: 8900-8911, 1998.

126. Hüttelmaier S, Zenklusen D, Lederer M, Dictenberg J, Lorenz M, Meng X, Bassell GJ, Condeelis J and Singer RH Spatial regulation of beta-actin translation by Src-dependent phosphorylation of ZBP1. Nature 438: 512-515, 2005

127. Giorgi $\mathrm{C}$ and Moore MJ: The nuclear nurture and cytoplasmic nature of localized mRNPs. Semin Cell Dev Biol 18: 186-193, 2007.

128. Sasaki Y, Welshhans K, Wen Z, Yao J, Xu M, Goshima Y, Zheng JQ and Bassell GJ: Phosphorylation of zipcode binding protein 1 is required for brain-derived neurotrophic factor signaling of local beta-actin synthesis and growth cone turning. J Neurosci 30: 9349-9358, 2010 
129. Brouwer JR, Willemsen R and Oostra BA: The FMR1 gene and fragile X-associated tremor/ataxia syndrome. Am J Med Genet B Neuropsychiatr Genet 150B: 782-798, 2009.

130. Sellier C, Rau F, Liu Y, Tassone F, Hukema RK, Gattoni R, Schneider A, Richard S, Willemsen R, Elliott DJ, Hagerman PJ and Charlet-Berguerand N: Sam68 sequestration and partial loss of function are associated with splicing alterations in FXTAS patients. EMBO J 29: 1248-1261, 2010

131.Gu W, Pan F, Zhang H, Bassell GJ and Singer RH: A predominantly nuclear protein affecting cytoplasmic localization of beta-actin mRNA in fibroblasts and neurons. J Cell Biol 156: 41-51, 2002.

132. Min H, Turck CW, Nikolic JM and Black DL: A new regulatory protein, KSRP, mediates exon inclusion through an intronic splicing enhancer. Genes Dev 11: 1023-1036, 1997.

133. Rehbein M, Kindler S, Horke S and Richter D: Two trans-acting rat-brain proteins, MARTA1 and MARTA2, interact specifically with the dendritic targeting element in MAP2 mRNAs. Brain Res Mol Brain Res 79: 192-201, 2000.

134. Rehbein M, Wege K, Buck F, Schweizer M, Richter D and Kindler S: Molecular characterization of MARTA1, a protein interacting with the dendritic targeting element of MAP2 mRNAs. J Neurochem 82: 1039-1046, 2002.

135.Pan F, Huttelmaier S, Singer RH and Gu W: ZBP2 facilitates binding of ZBP1 to beta-actin mRNA during transcription. Mol Cell Biol 27: 8340-8351, 2007.

136. White R, Gonsior C, Bauer NM, Krämer-Albers EM,Luhmann HJ and Trotter J: Heterogeneous nuclear ribonucleoprotein (hnRNP) $\mathrm{F}$ is a novel component of oligodendroglial RNA transport granules contributing to regulation of myelin basic protein (MBP) synthesis. J Biol Chem 287: 1742-1754, 2012.

137. Kiebler MA and Bassell GJ: Neuronal RNA granules: movers and makers. Neuron 51: 685-690, 2006.

138. Kelly RB and Grote E: Protein targeting in the neuron. Annu Rev Neurosci 16: 95-127, 1993.

139. Alvarez J, Giuditta A and Koenig E: Protein synthesis in axons and terminals: significance for maintenance, plasticity and regulation of phenotype. With a critique of slow transport theory. Prog Neurobiol 62: 1-62, 2000.

140. Satkauskas S and Bagnard D: Local protein synthesis in axonal growth cones: what is next? Cell Adh Migr 1: 179-184, 2007.

141. Giuditta A, Chun JT, Eyman M, Cefaliello C, Bruno AP and Crispino M: Local gene expression in axons and nerve endings: the glia-neuron unit. Physiol Rev 88: 515-555, 2008.

142. Twiss JL and Fainzilber M: Ribosomes in axons - scrounging from the neighbors? Trends Cell Biol 19: 236-243, 2009.

143.Perry RB and Fainzilber M: Local translation in neuronal processes-in vivo tests of a 'heretical hypothesis'. Dev Neurobiol: Aug 8, 2013 (Epub ahead of print).

144. Gumy LF, Katrukha EA, Kapitein LC and Hoogenraad CC: New insights into mRNA trafficking in axons. Dev Neurobiol: Aug 19, 2013 (Epub ahead of print).

145. Willis DE, Xu M,Donnelly CJ, Tep C, Kendall M, Erenstheyn M, English AW, Schanen NC, Kirn-Safran CB, Yoon SO, Bassell GJ and Twiss JL: Axonal localization of transgene mRNA in mature PNS and CNS neurons. J Neurosci 31: 14481-14487, 2011.

146.Donnelly CJ, Willis DE, Xu M, Tep C, Jiang C, Yoo S, Schanen NC, Kirn-Safran CB, van Minnen J, English A, Yoon SO, Bassell GJ and Twiss JL: Limited availability of ZBP1 restricts axonal mRNA localization and nerve regeneration capacity. EMBO J 30: 4665-4677, 2011.

147. Donnelly CJ, Park M, Spillane M, Yoo S, Pacheco A, Gomes C, Vuppalanchi D, McDonald M, Kim HH, Merianda TT, Gallo G and Twiss JL: Axonally synthesized beta-actin and GAP-43 proteins support distinct modes of axonal growth. J Neurosci 33: 3311-3322, 2013.

148. Welshhans K and Bassell GJ: Netrin-1-induced local beta-actin synthesis and growth cone guidance requires zipcode binding protein 1. J Neurosci 31: 9800-9813, 2011.

149.Jirikowski GF, Sanna PP and Bloom FE: mRNA coding for oxytocin is present in axons of the hypothalamo-neurohypophysial tract. Proc Natl Acad Sci USA 87: 7400-7404, 1990.

150. Trembleau A, Morales M and Bloom FE: Differential compartmentalization of vasopressin messenger RNA and neuropeptide within the rat hypothalamo-neurohypophysial axonal tracts: light and electron microscopic evidence. Neuroscience 70 : $113-125,1996$.

151.Eng H, Lund K and Campenot RB: Synthesis of beta-tubulin, actin, and other proteins in axons of sympathetic neurons in compartmented cultures. J Neurosci 19: 1-9, 1999.
152. Lee SK and Hollenbeck PJ: Organization and translation of mRNA in sympathetic axons. J Cell Sci 116: 4467-4478, 2003.

153. Antar LN, Li C, Zhang H, Carroll RC and Bassell GJ: Local functions for FMRP in axon growth cone motility and activitydependent regulation of filopodia and spine synapses. Mol Cell Neurosci 32: 37-48, 2006.

154. Litman P, Barg J, Rindzoonski L and Ginzburg I: Subcellular localization of tau mRNA in differentiating neuronal cell culture: implications for neuronal polarity. Neuron 10: 627-638, 1993.

155. Wu KY,Hengst U, Cox LJ, Macosko EZ, Jeromin A, Urquhart ER and Jaffrey SR: Local translation of RhoA regulates growth cone collapse. Nature 436: 1020-1024, 2005.

156. Bi J, Tsai NP, Lin YP, Loh HH and Wei LN: Axonal mRNA transport and localized translational regulation of kappa-opioid receptor in primary neurons of dorsal root ganglia. Proc Natl Acad Sci USA 103: 19919-19924, 2006

157. Willis D, Li KW, Zheng JQ, Chang JH, Smit A, Kelly T, Merianda TT, Sylvester J, van Minnen J and Twiss JL: Differential transport and local translation of cytoskeletal, injury-response, and neurodegeneration protein mRNAs in axons. J Neurosci 25: 778-791, 2005.

158. Cox LJ, Hengst U, Gurskaya NG, Lukyanov KA and Jaffrey SR: Intra-axonal translation and retrograde trafficking of CREB promotes neuronal survival. Nat Cell Biol 10: 149-159, 2008.

159. Willis DE, van Niekerk EA, Sasaki Y, Mesngon M, Merianda TT, Williams GG, Kendall M, Smith DS, Bassell GJ and Twiss JL: Extracellular stimuli specifically regulate localized levels of individual neuronal mRNAs. J Cell Biol 178: 965-980, 2007.

160. Yoon BC, Zivraj KH and Holt CE: Local translation and mRNA trafficking in axon pathfinding. Results Probl Cell Differ 48: 269-288, 2009.

161. Gumy LF, Yeo GS, Tung YC, Zivraj KH, Willis D, Coppola G, Lam BY, Twiss JL, Holt CE and Fawcett, JW: Transcriptome analysis of embryonic and adult sensory axons reveals changes in mRNA repertoire localization. RNA 17: 85-98, 2011

162. Koenig E: Organized ribosome-containing structural domains in axons. Results Probl Cell Differ 48: 173-191, 2009.

163. Tcherkezian J, Brittis PA, Thomas F, Roux PP and Flanagan JG: Transmembrane receptor DCC associates with protein synthesis machinery and regulates translation. Cell 141: 632-644, 2010.

164. Court FA, Hendriks WT, Macgillavry HD, Alvarez J and van Minnen J: Schwann cell to axon transfer of ribosomes: toward a novel understanding of the role of glia in the nervous system. J Neurosci 28: 11024-11029, 2008.

165. Sotelo JR, Canclini L, Kun A, Sotelo-Silveira JR, Xu L, Wallrabe H, Calliari A, Rosso G, Cal K and Mercer JA: MyosinVa-dependent cell-to-cell transfer of RNA from Schwann cells to axons. PLoS One 8: e61905, 2013.

166. Kapitein LC and Hoogenraad CC: Which way to go? Cytoskeletal organization and polarized transport in neurons. Mol Cell Neurosci 46: 9-20, 2011.

167. Franco SJ and Müller U: Shaping our minds: stem and progenitor cell diversity in the mammalian neocortex. Neuron 77: 19-34, 2013.

168. Douen AG, Dong L, Vanance S, Munger R, Hogan MJ, Thompson CS and Hakim AM: Regulation of nestin expression after cortical ablation in adult rat brain. Brain Res 1008: 139-146, 2004.

169. Brus M, Keller M and Lévy F: Temporal features of adult neurogenesis: differences and similarities across mammalian species. Front Neurosci 7: 135, 2013.

170. Kempermann G, Jessberger S, Steiner B and Kronenberg G: Milestones of neuronal development in the adult hippocampus. Trends Neurosci 27: 447-452, 2004.

171. Pan YW, Storm DR and Xia Z: Role of adult neurogenesis in hippocampus-dependent memory, contextual fear extinction and remote contextual memory: new insights from ERK5 MAP kinase. Neurobiol Learn Mem 105: 81-92, 2013.

172. Ming GL, Wong ST, Henley J, Yuan XB, Song HJ, Spitzer NC and Poo MM: Adaptation in the chemotactic guidance of nerve growth cones. Nature 417: 411-418, 2002.

173. Piper M, Salih S, Weinl C, Holt CE and Harris WA: Endocytosis-dependent desensitization and protein synthesisdependent resensitization in retinal growth cone adaptation. Nat Neurosci 8: 179-186, 2005.

174. Hörnberg $\mathrm{H}$ and Holt C: RNA-binding proteins and translational regulation in axons and growth cones. Front Neurosci 7: 81, 2013.

175. Charlesworth A, Meijer HA and de Moor CH: Specificity factors in cytoplasmic polyadenylation. Wiley Interdiscip Rev RNA 4: 437-461, 2013 
176. Richter JD: CPEB: a life in translation. Trends Biochem Sci 32 : 279-285, 2007.

177. Kundel M, Jones KJ, Shin CY and Wells DG: Cytoplasmic polyadenylation element-binding protein regulates neurotrophin3-dependent beta-catenin mRNA translation in developing hippocampal neurons. J Neurosci 29: 13630-13639, 2009.

178. Michlewski G, Guil S, Semple CA and Cáceres JF: Posttranscriptional regulation of miRNAs harboring conserved terminal loops. Mol Cell 32: 383-393, 2008.

179. Edbauer D, Neilson JR, Foster KA, Wang CF, Seeburg DP Batterton MN, Tada T, Dolan BM, Sharp PA and Sheng M: Regulation of synaptic structure and function by FMRPassociated microRNAs miR-125b and miR-132. Neuron 65 373-384, 2010.

180.Xu XL, Zong R, Li Z, Biswas MH, Fang Z, Nelson DL and Gao FB: FXR1P but not FMRP regulates the levels of mammalian brain-specific microRNA-9 and microRNA-124 J Neurosci 31: 13705-13709, 2011.

181. Hengst U, Cox LJ, Macosko EZ and Jaffrey SR: Functional and selective RNA interference in developing axons and growth cones. J Neurosci 26: 5727-5732, 2006.

182. Aschrafi A, Schwechter AD, Mameza MG, Natera-Naranjo O Gioio AE and Kaplan BB: microRNA-338 regulates local cytochrome c oxidase IV mRNA levels and oxidative phosphorylation in the axons of sympathetic neurons. J Neurosci 28: 12581-12590, 2008.

183. McKee AE, Minet E, Stern C, Riahi S, Stiles CD and Silver PA A genome-wide in situ hybridization map of RNA-binding proteins reveals anatomically restricted expression in the developing mouse brain. BMC Dev Biol 5: 14-22, 2005.

184. Gehman LT, Stoilov P, Maguire J, Damianov A, Lin CH, Shiue L, Ares M Jr, Mody I and Black DL: The splicing regulator Rbfox 1 (A2BP1) controls neuronal excitation in the mammalian brain. Nat Genet 43: 706-711, 2011

185. Hamada N, Ito H, Iwamoto I, Mizuno M, Morishita R, Inaguma $\mathrm{Y}$, Kawamoto $\mathrm{S}$, Tabata $\mathrm{H}$ and Nagata KI: Biochemica and morphological characterization of A2BP1 in neuronal tissue. J Neurosci Res 91: 1303-1311, 2013.

186. Kusek G, Campbell M, Doyle F, Tenenbaum SA, Kiebler M and Temple S: Asymmetric segregation of the double-stranded RNA binding protein Staufen2 during mammalian neural stem cell divisions promotes lineage progression. Cell Stem Cell 11: 505-516, 2012

187. Vessey JP, Amadei G, Burns SE, Kiebler MA, Kaplan DR and Miller FD: An asymmetrically localized Staufen2-dependent RNA complex regulates maintenance of mammalian neural stem cells. Cell Stem Cell 11: 517-528, 2012.

188. Nakamura M, Okano H, Blendy JA and Montell C: Musashi, a neural RNA-binding protein required for Drosophila adult external sensory organ development. Neuron 13: 67-81, 1994.

189. Kaneko Y, Sakakibara S, Imai T, Suzuki A, Nakamura Y, Sawamoto K, Ogawa Y, Toyama Y, Miyata T and Okano H: Musashil: an evolutionally conserved marker for CNS progenitor cells including neural stem cells. Dev Neurosci 22: 139-153, 2000

190. Maslov AY, Barone TA, Plunkett RJ and Pruitt SC: Neural stem cell detection, characterization, and age-related changes in the subventricular zone of mice. J Neurosci 24: 1726-1733, 2004.

191. Okano H, Kawahara H, Toriya M, Nakao K, Shibata S and Imai T: Function of RNA-binding protein Musashi-1 in stem cells. Exp Cell Res 306: 349-356, 2005.

192. Okamoto K, Nakatsukasa M, Alié A, Masuda Y, Agata K and Funayama N: The active stem cell specific expression of sponge Musashi homolog EflMsiA suggests its involvement in maintaining the stem cell state. Mech Dev 129: 24-37, 2012.

193. Sutherland JM, McLaughlin EA, Hime GR and Siddall NA: The musashi family of RNA binding proteins: master regulators of multiple stem cell populations. Adv Exp Med Biol 786: 233-245 2013.

194.Imai T, Tokunaga A, Yoshida T, Hashimoto M, Mikoshiba K, Weinmaster G, Nakafuku $M$ and Okano $H$ : The neural RNA-binding protein Musashil translationally regulates mammalian numb gene expression by interacting with its mRNA. Mol Cell Biol 21: 3888-3900, 2001.

195.Perez-Asensio FJ, Perpiñá U, Planas AM and Pozas E: Interleukin-10 regulates progenitor differentiation and modulates neurogenesis in adult brain. J Cell Sci 126: 4208-4219, 2013

196. Battelli C, Nikopoulos GN, Mitchell JG and Verdi JM: The RNA binding protein Musashi-1 regulates neural development through the translational repression of p21(WAF-1). Mol Cell Neurosci 31: 85-96, 2006
197. Akamatsu W, Okano HJ, Osumi N, Inoue T, Nakamura S, Sakakibara S, Miura M, Matsuo N, Darnell RB and Okano H: Mammalian ELAV-like neuronal RNA-binding proteins $\mathrm{HuB}$ and $\mathrm{HuC}$ promote neuronal development in both the central and the peripheral nervous systems. Proc Natl Acad Sci USA 96 9885-9890, 1999.

198. Akamatsu W, Fujihara H, Mitsuhashi T, Yano M, Shibata S, Hayakawa Y, Okano HJ, Sakakibara S, Takano H, Takano T, Takahashi T, Noda $\mathrm{T}$ and Okano H: The RNA binding protein $\mathrm{HuD}$ regulates neuronal cell identity and maturation. Proc Natl Acad Sci USA 102: 4625-4630, 2005.

199. Kasashima K, Terashima K, Yamamoto K, Sakashita E and Sakamoto H: Cytoplasmic localization is required for the mammalian ELAV-like protein HuD to induce neuronal differentiation. Genes Cells 4: 667-683, 1999.

200. Okano HJ and Darnell RB: A hierarchy of Hu RNA binding proteins in developing and adult neurons. J Neurosci 17: 3024-3037, 1997.

201. Szabo A, Dalmau J, Manley G, Rosenfeld M, Wong E, Henson J, Posner JB and Furneaux HM: HuD, a paraneoplastic encephalomyelitis antigen, contains RNA binding domains and is homologous to Elav and Sex-lethal. Cell 67: 325-333, 1991.

202. Darnell RB: RNA protein interaction in neurons. Annu Rev Neurosci 36: 243-270, 2013

203. Bolognani F, Merhege MA, Twiss J and Perrone-Bizzozero NI: Dendritic localization of the RNA-binding protein $\mathrm{HuD}$ in hippocampal neurons: association with polysomes and upregulation during contextual learning. Neurosci Lett 371: 152-157, 2004

204. Pascale A, Gusev PA, Amadio M, Dottorini T, Govoni S, Alkon DL and Quattrone A: Increase of the RNA-binding protein $\mathrm{HuD}$ and post-transcriptional upregulation of the GAP-43 gene during spatial memory. Proc Natl Acad Sci USA 101: 1217-1222, 2004

205. Clayton GH, Perez GM, Smith RL and Owens GC: Expression of mRNA for the elav-like neural-specific RNA binding protein, $\mathrm{HuD}$, during nervous system development. Brain Res Dev Brain Res 109: 271-280, 1998.

206. Pascale A, Amadio M and Quattrone A: Defining a neuron: neuronal ELAV proteins. Cell Mol Life Sci 65: 128-140, 2008

207. Ratti A, Fallini C, Colombrita C, Pascale A, Laforenza U, Quattrone A and Silani V: Post-transcriptional regulation of neuro-oncological ventral antigen 1 by the neuronal RNA-binding proteins ELAV. J Biol Chem 283: 7531-7541, 2008.

208. Ule J, Ule A, Spencer J, Williams A, Hu JS, Cline M, Wang H, Clark T, Fraser C, Ruggiu M, Zeeberg BR, Kane D, Weinstein JN, Blume J and Darnell RB: Nova regulates brain-specific splicing to shape the synapse. Nat Genet 37: 844-852, 2005

209. Ule J and Darnell RB: RNA binding proteins and the regulation of neuronal synaptic plasticity. Curr Opin Neurobiol 16: 102-110, 2006.

210. Wakamatsu Y and Weston JA: Sequential expression and role of $\mathrm{Hu}$ RNA-binding proteins during neurogenesis. Development 124: 3449-3460, 1997.

211. Quattrone A, Pascale A, Nogues X, Zhao W, Gusev P, Pacini A and Alkon DL: Posttranscriptional regulation of gene expression in learning by the neuronal ELAV-like mRNA-stabilizing proteins. Proc Natl Acad Sci USA 98: 11668-11673, 2001.

212. Bolognani F, Qiu S, Tanner DC, Paik J, Perrone-Bizzozero NI and Weeber EJ: Associative and spatial learning and memory deficits in transgenic mice overexpressing the RNA-binding protein HuD. Neurobiol Learn Mem 87: 635-643, 2007.

213. Smith CL, Afroz R, Bassell GJ, Furneaux HM, Perrone-Bizzozero NI and Burry RW: GAP-43 mRNA in growth cones is associated with HuD and ribosomes. J Neurobiol 61: 222-235, 2004

214.Lim CS and Alkon DL: Protein kinase C stimulates HuD-mediated mRNA stability and protein expression of neurotrophic factors and enhances dendritic maturation of hippocampal neurons in culture. Hippocampus 22: 2303-2319, 2012.

215. Iijima T, Imai T, Kimura Y, Bernstein A, Okano HJ, Yuzaki M and Okano H: Hzf protein regulates dendritic localization and BDNF-induced translation of type 1 inositol 1,4,5 trisphosphate receptor mRNA. Proc Natl Acad Sci USA 102: 17190-17195, 2005.

216. Iijima T, Ogura H, Takatsuki K, Kawahara S, Wakabayashi K, Nakayama D, Fujioka M, Kimura Y, Bernstein A, Okano HJ, Kirino $\mathrm{Y}$ and Okano H: Impaired motor functions in mice lacking the RNA-binding protein Hzf. Neurosci Res 58: 183-189, 2007. 
217. Miller S, Yasuda M, Coats JK, Jones Y, Martone ME and Mayford M: Disruption of dendritic translation of CaMKIIalpha impairs stabilization of synaptic plasticity and memory consolidation. Neuron 36: 507-519, 2002.

218. Bassell GJ and Warren ST: Fragile X syndrome: loss of local mRNA regulation alters synaptic development and function. Neuron 60: 201-214, 2008.

219.Pfeiffer BE and Huber KM: The state of synapses in fragile $X$ syndrome. Neuroscientist 15: 549-567, 2009

220. Sidorov MS, Auerbach BD and Bear MF: Fragile X mental retardation protein and synaptic plasticity. Mol Brain 6: 15, 2013

221. Westmark CJ and Malter JS: FMRP mediates mGluR5dependent translation of amyloid precursor protein. PLoS Biol 5: e52, 2007.

222. Ascano M Jr, Mukherjee N, Bandaru P, Miller JB, Nusbaum JD Corcoran DL, Langlois C, Munschauer M, Dewell S, Hafner M, Williams Z, Ohler U and Tuschl T: FMRP targets distinct mRNA sequence elements to regulate protein expression. Nature 492: 382-386, 2012.

223. Dictenberg JB, Swanger SA, Antar LN, Singer RH and Bassell GJ: A direct role for FMRP in activity-dependent dendritic mRNA transport links filopodial-spine morphogenesis to fragile X syndrome. Dev Cell 14: 926-939, 2008.

224.Zhao MG, Toyoda H, Ko SW, Ding HK, Wu LJ and Zhuo M: Deficits in trace fear memory and long-term potentiation in a mouse model for fragile X syndrome. J Neurosci 25: 7385-7392, 2005.

225.Dölen G, Osterweil E, Rao BS, Smith GB, Auerbach BD, Chattarji $\mathrm{S}$ and Bear MF: Correction of fragile $\mathrm{X}$ syndrome in mice. Neuron 56: 955-962, 2007.

226. Iacoangeli A and Tiedge H: Translational control at the synapse: role of RNA regulators. Trends Biochem Sci 38: 47-55, 2013.

227. Luo Y, Shan G, Guo W, Smrt RD, Johnson EB, Li X, Pfeiffer RL, Szulwach KE, Duan R, Barkho BZ, Li W, Liu C, Jin P and Zhao X: Fragile x mental retardation protein regulates proliferation and differentiation of adult neural stem/progenitor cells. PLoS Genet 6: e1000898, 2010.
228. Guo W, Allan AM, Zong R, Zhang L, Johnson EB, Schaller EG, Murthy AC, Goggin SL, Eisch AJ, Oostra BA, Nelson DL, Jin $\mathrm{P}$ and Zhao X: Ablation of Fmrp in adult neural stem cells disrupts hippocampus-dependent learning. Nat Med 17: 559-565, 2011.

229. Krueger DD, Osterweil EK, Chen SP, Tye LD and Bear MF: Cognitive dysfunction and prefrontal synaptic abnormalities in a mouse model of fragile X syndrome. Proc Natl Acad Sci USA 108: 2587-2592, 2011

230. Stein JM, Bergman W, Fang Y, Davison L, Brensinger C, Robinson MB, Hecht NB and Abel T: Behavioral and neurochemical alterations in mice lacking the RNA-binding protein translin. J Neurosci 26: 2184-2196, 2006.

231. Chen-Plotkin AS, Lee VM and Trojanowski JQ: TAR DNA-binding protein 43 in neurodegenerative disease. Nat Rev Neurol 6: 211-220, 2010.

232. Kwong LK, Uryu K, Trojanowski JQ and Lee VM: TDP-43 proteinopathies: neurodegenerative protein misfolding diseases without amyloidosis. Neurosignals 16: 41-51, 2008.

233. Aparicio-Erriu IM and Prehn JH: Molecular mechanisms in amyotrophic lateral sclerosis: the role of angiogenin, a secreted RNase. Front Neurosci 6: 167, 2012.

234. Ivanov P, Emara MM, Villen J, Gygi SP and Anderson P: Angiogenin-induced tRNA fragments inhibit translation initiation. Mol Cell 43: 613-623, 2011.

235. Tadesse H, Deschênes-Furry J, Boisvenue S and Côté J: KH-type splicing regulatory protein interacts with survival motor neuron protein and is misregulated in spinal muscular atrophy. Hum Mol Genet 17: 506-524, 2008.

236. Glinka M, Herrmann T, Funk N, Havlicek S, Rossoll W, Winkler C and Sendtner M: The heterogeneous nuclear ribonucleoprotein-R is necessary for axonal beta-actin mRNA translocation in spinal motor neurons. Hum Mol Genet 19: 1951-1966, 2010. 